\title{
Stakeholder involvement in systematic reviews: a scoping review
}

\author{
Alex Pollock ${ }^{1 *}$ (D, Pauline Campbell ${ }^{1}$, Caroline Struthers ${ }^{2}$, Anneliese Synnot ${ }^{3,4}$, Jack Nunn ${ }^{5}$, Sophie Hill ${ }^{3}$, \\ Heather Goodare ${ }^{6}$, Jacqui Morris ${ }^{7}$, Chris Watts ${ }^{8}$ and Richard Morley ${ }^{9}$
}

\begin{abstract}
Background: There is increasing recognition that it is good practice to involve stakeholders (meaning patients, the public, health professionals and others) in systematic reviews, but limited evidence about how best to do this. We aimed to document the evidence-base relating to stakeholder involvement in systematic reviews and to use this evidence to describe how stakeholders have been involved in systematic reviews.
\end{abstract}

Methods: We carried out a scoping review, following a published protocol. We searched multiple electronic databases (2010-2016), using a stepwise searching approach, supplemented with hand searching. Two authors independently screened and discussed the first 500 abstracts and, after clarifying selection criteria, screened a further 500. Agreement on screening decisions was 97\%, so screening was done by one reviewer only. Pre-planned data extraction was completed, and the comprehensiveness of the description of methods of involvement judged. Additional data extraction was completed for papers judged to have most comprehensive descriptions. Three stakeholder representatives were co-authors for this systematic review.

Results: We included 291 papers in which stakeholders were involved in a systematic review. Thirty percent involved patients and/or carers. Thirty-two percent were from the USA, 26\% from the UK and 10\% from Canada. Ten percent (32 reviews) were judged to provide a comprehensive description of methods of involving stakeholders. Sixty-nine percent (22/32) personally invited people to be involved; 22\% (7/32) advertised opportunities to the general population. Eighty-one percent (26/32) had between 1 and 20 face-to-face meetings, with $83 \%$ of these holding $\leq 4$ meetings. Meetings lasted $1 \mathrm{~h}$ to $1 / 2$ day. Nineteen percent (6/32) used a Delphi method, most often involving three electronic rounds. Details of ethical approval were reported by 10/32. Expenses were reported to be paid to people involved in 8/32 systematic reviews.

Discussion/conclusion: We identified a relatively large number (291) of papers reporting stakeholder involvement in systematic reviews, but the quality of reporting was generally very poor. Information from a subset of papers judged to provide the best descriptions of stakeholder involvement in systematic reviews provide examples of different ways in which stakeholders have been involved in systematic reviews. These examples arguably currently provide the best available information to inform and guide decisions around the planning of stakeholder involvement within future systematic reviews. This evidence has been used to develop online learning resources.

Systematic review registration: The protocol for this systematic review was published on 21 April 2017. Publication reference: Pollock A, Campbell P, Struthers C, Synnot A, Nunn J, Hill S, Goodare H, Watts C, Morley R: Stakeholder involvement in systematic reviews: a protocol for a systematic review of methods, outcomes and effects. Research Involvement and Engagement 2017, 3:9. https://doi.org/10.1186/s40900-017-0060-4.

Keywords: Systematic review, Scoping review, Involvement, Stakeholder, Patient, Public, Consumer

\footnotetext{
* Correspondence: alex.pollock@gcu.ac.uk

${ }^{1}$ Nursing Midwifery and Allied Health Professions (NMAHP) Research Unit,

Glasgow Caledonian University, Cowcaddens Road, Glasgow G4 OBA, UK

Full list of author information is available at the end of the article
}

(c) The Author(s). 2018 Open Access This article is distributed under the terms of the Creative Commons Attribution 4.0 International License (http://creativecommons.org/licenses/by/4.0/), which permits unrestricted use, distribution, and reproduction in any medium, provided you give appropriate credit to the original author(s) and the source, provide a link to the Creative Commons license, and indicate if changes were made. The Creative Commons Public Domain Dedication waiver (http://creativecommons.org/publicdomain/zero/1.0/) applies to the data made available in this article, unless otherwise stated. 


\section{Background}

The concept of active involvement in research of people with a healthcare condition, their families, friends and carers, was founded on the principle that people affected by the condition have a moral right to contribute to decisions about what research is undertaken and in what way [1-3]. The active involvement of other stakeholders (meaning patients, the public, health professionals, health decision makers and funders) grew from a desire to address the lack of real-world relevance of research and to ensure more effective implementation of research findings into practice $[4,5]$. It is now widely accepted in many parts of the world that the active involvement of many of these groups (that we collectively refer to as 'stakeholders') is beneficial to the quality, relevance and impact of health research [2, 3]. Accordingly, many funding bodies, including government and charities, now mandate that researchers actively involve patients and the public in their research, including systematic reviews [6-9], although there is evidence of international variation in the extent to which patients and the public are involved [10].

Systematic reviews aim to inform and support the delivery of evidence-based practice, by finding and bringing together, in an explicit and transparent way, all the research evidence that addresses a particular topic or healthcare question. Stakeholder involvement within systematic reviews has been proposed as a way to enhance the actual and perceived usefulness of synthesised research evidence, addressing barriers to the uptake of evidence into practice [11]. In this paper, we define (based on a number of published definitions, e.g. $[1,12,13])$ 'active stakeholder involvement' as the contribution of people who are not researchers throughout the process of production and dissemination of a systemic review, including the planning and conduct of an individual systematic review. While there are a number of examples of active stakeholder involvement in systematic reviews, the approaches to, and extent of, involvement have varied considerably [14-16] and synthesised evidence and resources to guide practice is lacking. As well as active involvement within individual systematic reviews, stakeholders may also get involved at the level of organisations which commission or carry out systematic reviews. A recent review explored examples of consumer involvement within organisations (such as Cochrane) that support production of systematic reviews [17], but evidence relating to relevant activities and roles of individual researchers and how they may involve stakeholders in their reviews remains scant [18].

As part of a wider project to provide guidance to researchers about how to involve stakeholders in systematic reviews [19], we undertook a mixed-method evidence synthesis, first completing a scoping review to create a broad map of evidence relating to stakeholder involvement in systematic reviews, followed by two contingent syntheses [20]. Here, we report the results of the scoping review. The aims of this paper are therefore to:

1. Document the evidence-base relating to stakeholder involvement in systematic reviews

2. Use this evidence to describe key features of how stakeholders have been involved in systematic reviews

\section{Methods \\ Design}

We carried out a scoping review, following a protocol [20]. We followed the methodological steps outlined by Arksey and O'Malley [21] and used an iterative team approach, with regular team meetings to discuss progress and reach consensus on next steps, to ensure clarity of purpose and balance between breadth and comprehensiveness of the review [21-23]. Protocol deviations, with justifications, are described in Additional file 1.

\section{Search strategy}

We implemented a stepwise approach [24] to promote efficient identification of up-to-date literature, balancing the expected large volume of literature with available time and resources. Details of this approach, including pre-agreed criteria and contingencies to inform decisions relating to the extent of the searches, have previously been described [20]; below we report the actual steps of searching and brief justification for these steps.

We used a comprehensive search strategy, adapted for each database (see Additional file 2). In step 1, we searched a comprehensive set of databases (CENTRAL (CDSR, DARE, HTA, Cochrane Methodology Register), Embase (Ovid), MEDLINE (Ovid), CINAHL (EBSCO), AMED, Joanna Briggs Database and ProQuest Dissertations and Theses (handsearched)), within a narrow time period (from 01 January 2014 to 09 April 2016). The aim of step 1 was to, in an efficient way, identify the databases most likely to include relevant papers. In step 2, we searched a more limited set of databases (Embase, MEDLINE, CINAHL and HTA) for a longer time period (01 January 2010 to 31 December 2013) with the aim of exploring whether there was justification for extending the search beyond 2010.

Searching and application of inclusion criteria was applied to each step prior to progression to the next step. For step 1, we noted the source database (or databases) of each identified record, and the databases from which the greatest number of included papers were identified. The results of these explorations were discussed and review team consensus reached on which databases to include in step 2. After step 2, the review team explored 
the publication dates of records meeting our inclusion criteria. The majority of papers meeting our inclusion criteria (63\%) were published in either 2014 or 2015 (see Additional file 3). The sharp drop in numbers of included papers from 2014 to 2013 and relatively stable number of included papers between 2013 and 2010 were key factors in the team decision not to extend electronic searching to before 2010 .

Additional sources we searched include the reference lists of recent relevant reports and reviews (e.g. [6, 17, $25])$, the reference lists of all included studies and articles published in the journal Research Involvement and Engagement. To identify unpublished reports, we contacted authors of published papers and promoted this review via social media.

\section{Selection criteria}

Selection criteria for inclusion were purposefully wide. We included any paper, published or unpublished, regardless of study design, including commentaries, letters and expert opinion, which investigated, reported or discussed any aspect of stakeholder involvement in a systematic review. We anticipated that we would include (but would not be limited to) evidence such as published systematic reviews which reported involvement; reports of methods of involvement in an individual systematic review; studies quantitatively or qualitatively evaluating involvement in individual systematic reviews; and opinions, commentary and discussion relating to involvement in systematic reviews.

We excluded papers that focussed on stakeholder involvement in the generation of research priorities (unless they were specifically generating questions for a systematic review) and in both research more broadly, and guideline development, unless there was an explicit mention of involvement in systematic reviews. Systematic reviews that focussed on synthesising the evidence related to stakeholder involvement in primary research were also excluded. We excluded titles without abstracts and review protocols; this was a pragmatic decision made in light of the high volume of search results.

\section{Definition of key terms}

We used the following operational definitions, pre-stated in the protocol [20], to support the application of the selection criteria:

- Stakeholder-any person who would be a knowledge user of research but whose primary role is not directly in research. Potential stakeholders include a broad range of people, including those who are actual or potential recipients of health or social care, where this may include patients, carers and family members, or people interested in remaining healthy who are seeking information about a health condition or treatment for personal use [26]; members of organisations that represent people who use services; people with a professional role in health and social care; policy makers and managers. We documented the types of people involved within any evidence included in this review, highlighting where this included patients, carers and family members, and where this included other stakeholders only.

- Systematic review-a research process in which literature relevant to a stated question is identified and brought together (synthesised) using explicit methods [27], including reporting of inclusion/ exclusion criteria, search methods and details of included studies. We accepted systematic reviews regardless of the type of evidence synthesised (i.e. quantitative, qualitative, mixed-methods) and the type of question addressed (e.g. intervention effectiveness, diagnostic test accuracy, patient experiences).

- Involvement in a systematic review-any role or contribution of stakeholders toward the development of a review protocol, completion of any of the stages of a systematic review or dissemination of the findings of a review.

\section{Methods of applying selection criteria}

One review author (PC) ran the search strategy and excluded any obviously irrelevant titles. Two reviewers (PC, AP) independently reviewed the abstracts and applied selection criteria to the first 500 records; agreement was explored and a full team discussion held to clarify the selection criteria. This clarification led to a number of post hoc exclusion criteria (described above under selection criteria and within Additional file 1). Subsequently, we agreed that two independent review authors (PC, AP) should review a further 500 records using the clarified criteria and that if agreement between independent reviewers was greater than 95\% when using these refined criteria, then subsequent selection of papers would be performed by one reviewer only; this agreement was 97\%, and therefore, one reviewer (AP) screened the remaining abstracts. The full papers from abstracts included after the screening process were considered at the data extraction and judgement stages (see below); if a paper was found not to meet the inclusion criteria at this stage, it was excluded.

\section{Data extraction and synthesis Data extraction}

For all included papers, one reviewer (AP) extracted and categorised data into structured tables. Extracted data included bibliographic information, type of paper, stated 
aim, topic/focus of systematic review, study/review methodology, description of reported involvement, details of people involved, stage in review process at which people involved and any formal research methods used. Retrospective categorisation of data included focus of review and type of evidence synthesised (see Additional file 1, protocol deviations). Details of the operationalisation of these data extraction items are provided in Additional file 4.

\section{Judgement of comprehensiveness of description}

Our review aim was to describe key features of how stakeholders have been involved in systematic reviews; consequently, we were principally concerned with the comprehensiveness of the description of methods of involvement, rather than appraising the quality of the methods of the reviews. We devised a method for judging the comprehensiveness of the description of the method or approach to involvement, given that there are no standardised tools for such a task. Criteria for categorising the comprehensiveness of the description provided within papers were developed, adapted from Pollock [28]. Initially, two reviewers (AP, CS) assigned these criteria independently for a random sample of $20 \%$ of papers identified from step 1 of searching; this was 42 of 210 papers. There was agreement between independent reviewers for $57 \%(24 / 42)$ of the assessed sample. The agreement between reviewers, implications relating to disagreements and perceived risk of bias to the review results are reported in Additional file 5. Following discussion and clarification of criteria (see Additional file 5), it was agreed that one reviewer would assign judgements to the remaining papers, using the following criteria:

- 'Green'-comprehensive description of one (or more) specific method or approach to the involvement of stakeholders in systematic reviews. Description sufficient to enable replication of methods

- 'Amber'-a brief or partial description of one (or more) specific method or approach to the involvement of stakeholders in systematic reviews. Description sufficient to enable partial replication of methods

- 'Red'-few details provided and/or inadequate description of the method or approach of involvement of stakeholders in systematic reviews. Description insufficient to enable any replication of methods

\section{Detailed description of methods or approaches to involvement}

Additional, more detailed, data extraction was performed for papers that were judged as 'green' for comprehensiveness of description. In addition to a narrative description of the methods or approaches to involvement, one reviewer (AP) extracted and tabulated the stated aim of involvement, number and characteristics of people involved, methods of recruitment, format of involvement (e.g. face-to-face meeting, telephone meeting, written consultation, online survey), amount of involvement (number of meetings, number of days involved), details of ethical approval and financial compensation given to stakeholders, evaluation of the involvement and tools used for reporting involvement.

\section{Stakeholder involvement in this systematic review}

One consumer (HG) and two consumer representatives (RM, CS) were members of the project and author team for this systematic review. All contributed to face-to-face discussions which led to the development of the review protocol, and read, commented on and had authorship of the published protocol. All contributed to project teleconferences throughout the review, particularly when making decisions relating to the stepwise search methods. Additionally, CS independently applied judgements of comprehensiveness to a sample of full papers. All three discussed the key findings of this review and contributed as authors to the final manuscript.

\section{Results}

\section{Results of the search}

We screened 12,908 titles and abstracts and applied selection criteria to 672 full papers. Three hundred sixty-nine of these 672 full papers were excluded: 118 as they were abstracts only, 18 as they were protocols, 16 as they were duplicates and 217 as they did not meet our inclusion criteria. Reasons that these 217 did not meet our inclusion criteria are listed in table of excluded studies (Additional file 6); main reasons for exclusion were that the paper was a systematic review but there was no involvement of people (approximately 30\%), the paper did not describe or report a systematic review (approximately $25 \%$ ) or the paper described involvement in research other than a systematic review (approximately 25\%). This left 291 papers that met our criteria for inclusion in the scoping review (see Fig. 1).

\section{Characteristics of included papers}

Details of the 291 included papers are provided in the table of included studies (Additional file 7). A brief summary is described below.

\section{Type of paper}

Thirty-one percent of included papers were published systematic reviews; $54 \%$ were reports of a guideline or recommendation in which a systematic review component was described; and $5 \%$ were papers specifically 


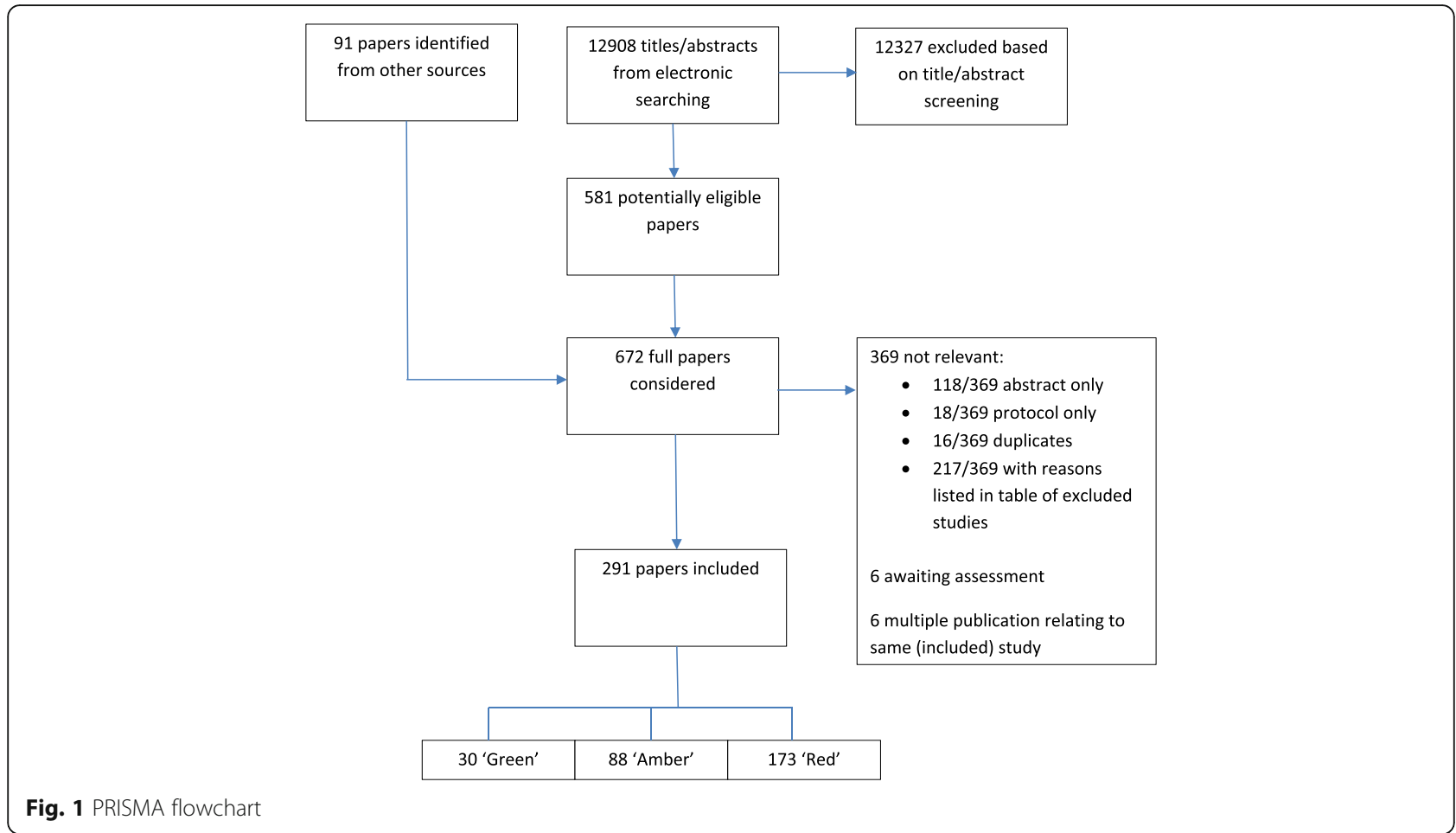

describing methods of involving stakeholders in a systematic review.

\section{Stakeholders involved}

Thirty percent of the included papers involved patients and/or carers within the systematic review process, while $41 \%$ involved other stakeholders (e.g. health professionals, academic experts, representatives of patient organisations) but not patients or their family members. In almost one third of the included papers (29\%), it was not clear who the stakeholders involved in the review were and whether this included patients and/or carers.

\section{Country}

One third (31.6\%) of papers were from the USA, one quarter $(26.1 \%)$ from the UK and $10.0 \%$ from Canada. Of the remaining papers, $22.7 \%$ were from Australia, Netherlands, Germany, Italy, France or Spain, and 9.6\% from a further 15 countries with between 1 and 4 papers each (see Table 1).

\section{Stage of the review process}

In almost half of the papers (47.8\%), the stage of the review process at which stakeholders were involved was unclear. In just over one quarter (27.5\%), stakeholders were involved in interpreting the results after the

Table 1 Country in which stakeholder involvement took place/country of lead author

\begin{tabular}{|c|c|c|c|c|c|c|c|c|}
\hline \multirow[b]{2}{*}{ USA } & \multicolumn{2}{|c|}{ Total } & \multicolumn{2}{|c|}{ Patients/carers included } & \multicolumn{2}{|c|}{ No patients/carers included } & \multicolumn{2}{|c|}{ Unclear } \\
\hline & 92 & $31.6 \%$ & 18 & $19.6 \%$ & 42 & $45.7 \%$ & 32 & $34.8 \%$ \\
\hline UK & 76 & $26.1 \%$ & 42 & $55.3 \%$ & 16 & $21.1 \%$ & 18 & $23.7 \%$ \\
\hline Canada & 29 & $10.0 \%$ & 3 & $10.3 \%$ & 17 & $58.6 \%$ & 9 & $31.0 \%$ \\
\hline Australia & 22 & $7.6 \%$ & 5 & $22.7 \%$ & 7 & $31.8 \%$ & 10 & $45.5 \%$ \\
\hline Netherlands & 14 & $4.8 \%$ & 8 & $57.1 \%$ & 4 & $28.6 \%$ & 2 & $14.3 \%$ \\
\hline Germany & 12 & $4.1 \%$ & 2 & $16.7 \%$ & 8 & $66.7 \%$ & 2 & $16.7 \%$ \\
\hline Italy & 7 & $2.4 \%$ & 1 & $14.3 \%$ & 4 & $57.1 \%$ & 2 & $28.6 \%$ \\
\hline France & 6 & $2.1 \%$ & 1 & $16.7 \%$ & 3 & $50.0 \%$ & 2 & $33.3 \%$ \\
\hline Spain & 5 & $1.7 \%$ & 3 & $60.0 \%$ & 1 & $20.0 \%$ & 1 & $20.0 \%$ \\
\hline Other (countries with $<5$ papers*) & 28 & $9.6 \%$ & 5 & $17.9 \%$ & 17 & $60.7 \%$ & 6 & $21.4 \%$ \\
\hline
\end{tabular}

*Austria, China, Japan, Saudi Arabia, Switzerland, Belgium, Denmark, Norway, Brazil, Chile, Columbia, Iran, Korea, New Zealand, Taiwan 
evidence had been synthesised. In around one fifth (22.3\%), stakeholders were involved either throughout the whole review process or during one or more stages of review completion (see Table 2).

\section{Focus of the review}

Seventy-one percent of the included systematic reviews were judged to be focussed on one of the International Statistical Classification of Diseases and Related Health Problems 10th Revision (ICD-10) categories (Table 3 and table of included studies (Additional file 7)). Most frequently (10\%), this was 'factors influencing health status and contact with health services', where reviews covered topics such as the effectiveness or implementation of care pathways for specific population (e.g. paediatrics, geriatrics, emergency care). The specific diseases or health areas covered by the greatest numbers of reviews were mental and behavioural disorders (8.6\%), neoplasms (6.9\%), diseases of the musculoskeletal system and connective tissue (6.2\%) and certain infectious and parasitic diseases (5.5\%). Thirteen percent of the reviews which did not fit one of the ICD-10 categories were focussed on a specific intervention, most commonly medical or surgical interventions $(8.6 \%)$ and public health interventions (5.2\%). Ten percent of reviews were focussed on an area of research, rather than a specific health or disease area or intervention; more than half of these $(55 \%, n=29)$ were focussed on methods of stakeholder involvement or engagement, while the remainder focussed on other areas of research methods, such as methods of statistical tests within primary research. The remaining $7 \%$ were unable to be categorised within any of these groups and focussed on, for example, areas such as teaching, data protection and criminal justice.

\section{Comprehensiveness of description of method or approach to involvement}

Table 4 shows the assigned judgements of the comprehensiveness of the description of the method or approach to involvement. Figure 2 illustrates the proportion of different types of paper which were judged to be 'green', 'amber' or 'red', when patients/carers were involved and at different stages in the review process.
In total, $59 \%$ of the included papers were judged to provide few or inadequate details ('red'), with only $10 \%$ judged to provide a comprehensive description of one, or more, method or approach to involvement ('green').

\section{Detailed description of methods or approaches to involvement}

The 30 papers which were judged as providing a comprehensive ('green') description of their methods or approaches to involvement included 14 'methods' papers describing an experience of stakeholder involvement in one (or more) systematic review [25, 29-41]; 11 systematic reviews in which the stakeholder involvement was concurrently described [42-52]; 2 guidelines or clinical recommendations, in which the involvement in the systematic review component was described [53, 54]; and 1 paper which described the development of a tool to report stakeholder involvement [55]. Two of the papers each described two different systematic reviews [37, 55], meaning that there are a total of 32 systematic review described. Table 5 summarises the key characteristics of these 32 systematic reviews, and Table 6 summarises the data relating to stakeholder involvement and a brief narrative summary of key features is provided below.

\section{Review aim/focus}

Table 5 states the aim and focus of the 32 systematic review. Sixty-eight percent were focussed on one of the ICD-10 categories; with mental and behavioural disorders being the most common health topic (22\%). Sixteen percent were focussed on a specific intervention rather than a disease area, most commonly on a public health intervention (12\%). The remaining $16 \%$ were focussed on either research or another topic.

A majority of the reviews (56\%) synthesised both qualitative and quantitative evidence, while $19 \%$ only included quantitative studies and $12.5 \%$ only included qualitative studies. The type of evidence included was unclear for $12.5 \%$. Two of the reviews described using a 'realist' review methodology, and 2 were Cochrane reviews of randomised controlled trials.

Table 2 Stage of the review process in which stakeholders were involved

\begin{tabular}{|c|c|c|c|c|c|c|c|c|}
\hline \multirow[b]{2}{*}{ Setting scope/review questions } & \multicolumn{2}{|c|}{ Total $^{*}$} & \multicolumn{2}{|c|}{ Patients/carers involved } & \multicolumn{2}{|c|}{ No patients/carers involved } & \multicolumn{2}{|c|}{ Unclear } \\
\hline & 25 & $8.59 \%$ & 8 & $32.00 \%$ & 15 & $60.00 \%$ & 2 & $8.00 \%$ \\
\hline Interpreting results after review completion & 80 & $27.49 \%$ & 27 & $33.75 \%$ & 39 & $48.75 \%$ & 14 & $17.50 \%$ \\
\hline Throughout/within the review process & 65 & $22.34 \%$ & 36 & $55.40 \%$ & 24 & $36.90 \%$ & 5 & $7.70 \%$ \\
\hline unclear & 139 & $47.77 \%$ & 22 & $15.80 \%$ & 52 & $37.40 \%$ & 65 & $46.80 \%$ \\
\hline
\end{tabular}

*Percentages are calculated as percentage of the 291 papers with involvement at that stage. Total adds up to $>100 \%$, as 18 papers involved stakeholders at both setting scope/review questions and interpreting results after review completion and have therefore been counted within both of these categories 
Table 3 Focus of review

\begin{tabular}{|c|c|c|c|c|}
\hline & Total & Patients/carers included & No patients/carers included & Unclear \\
\hline Research & $2910.0 \%$ & $1655.2 \%$ & $724.1 \%$ & $620.7 \%$ \\
\hline XXI Factors influencing health status and contact with health services & $289.6 \%$ & $932.1 \%$ & $1553.6 \%$ & $414.3 \%$ \\
\hline V Mental and behavioural disorders & $258.6 \%$ & $1248.0 \%$ & $416.0 \%$ & $936.0 \%$ \\
\hline II Neoplasms & $206.9 \%$ & $735.0 \%$ & $735.0 \%$ & $630.0 \%$ \\
\hline $\mathrm{ICHI}$ Medical and surgical intervention & $206.9 \%$ & $15.0 \%$ & $1260.0 \%$ & $735.0 \%$ \\
\hline XIII Diseases of the musculoskeletal system and connective tissue & $186.2 \%$ & $633.3 \%$ & $1055.6 \%$ & $211.1 \%$ \\
\hline I Certain infectious and parasitic diseases & $165.5 \%$ & $425.0 \%$ & $1062.5 \%$ & $212.5 \%$ \\
\hline ICHI Public health intervention & $155.2 \%$ & $320.0 \%$ & $853.3 \%$ & $426.7 \%$ \\
\hline XI Diseases of the digestive system & $144.8 \%$ & $00.0 \%$ & $642.9 \%$ & $857.1 \%$ \\
\hline$X$ Diseases of the respiratory system & $134.5 \%$ & $215.4 \%$ & $861.5 \%$ & $323.1 \%$ \\
\hline IV Endocrine, nutritional and metabolic diseases & $124.1 \%$ & $18.3 \%$ & $650.0 \%$ & $541.7 \%$ \\
\hline IX Diseases of the circulatory system & $124.1 \%$ & $216.7 \%$ & $433.3 \%$ & $650.0 \%$ \\
\hline XII Diseases of the skin and subcutaneous tissue & $82.7 \%$ & $337.5 \%$ & $450.0 \%$ & $112.5 \%$ \\
\hline XIV Diseases of the genitourinary system & $82.7 \%$ & $337.5 \%$ & $337.5 \%$ & $225.0 \%$ \\
\hline XV Pregnancy, childbirth and the puerperium & $82.7 \%$ & $450.0 \%$ & $225.0 \%$ & $225.0 \%$ \\
\hline XIX Injury, poisoning and certain other consequences of external causes & $72.4 \%$ & $00.0 \%$ & $342.9 \%$ & $457.1 \%$ \\
\hline VI Diseases of the nervous system & $51.7 \%$ & $240.0 \%$ & $240.0 \%$ & $120.0 \%$ \\
\hline Categories with $<5$ papers* & $144.8 \%$ & $750.0 \%$ & $17.1 \%$ & $642.9 \%$ \\
\hline Other (unable to categorise) & $196.5 \%$ & $631.6 \%$ & $736.8 \%$ & $631.6 \%$ \\
\hline
\end{tabular}

Note: no papers were categorised as XVI Certain conditions originating in the perinatal period; XVIII Symptoms, signs and abnormal clinical and laboratory findings, not elsewhere classified

*III Diseases of the blood and blood-forming organs and certain disorders involving the immune mechanism; VII Diseases of the eye and adnexa; VIII Diseases of the ear and mastoid process; XVII Congenital malformations, deformations and chromosomal abnormalities; XX External causes of morbidity and mortality; ICHI Functioning intervention

Table 4 Comprehensiveness of description of method or approach to involvement

\begin{tabular}{|c|c|c|c|}
\hline Comprehensiveness & 'Green' $\mathrm{O}$ & 'Amber' $\bigcirc$ & 'Red' $\bigcirc$ \\
\hline & $\begin{array}{l}\text { Comprehensive description of one (or } \\
\text { more) specific method or approach to } \\
\text { the involvement in systematic reviews. } \\
\text { Description sufficient to enable } \\
\text { replication of methods }\end{array}$ & $\begin{array}{l}\text { A brief or partial description of one (or } \\
\text { more) specific method or approach to } \\
\text { the involvement in systematic reviews. } \\
\text { Description sufficient to enable partial } \\
\text { replication of methods }\end{array}$ & $\begin{array}{l}\text { Few details provided and/or inadequate } \\
\text { description of the method or approach } \\
\text { of involvement. Description insufficient } \\
\text { to enable any replication of methods }\end{array}$ \\
\hline Total & 30 & 88 & 173 \\
\hline \multicolumn{4}{|c|}{ Were patients/consumers involved? } \\
\hline Yes & 24 & 37 & 27 \\
\hline No & 5 & 38 & 76 \\
\hline Unclear & 1 & 13 & 70 \\
\hline \multicolumn{4}{|c|}{ Stage at which there was involvement* } \\
\hline $\begin{array}{l}\text { Setting scope/ } \\
\text { review questions }\end{array}$ & 7 & 11 & 7 \\
\hline $\begin{array}{l}\text { Interpreting } \\
\text { results after } \\
\text { review } \\
\text { completion }\end{array}$ & 10 & 41 & 29 \\
\hline $\begin{array}{l}\text { Throughout/ } \\
\text { within the } \\
\text { review process }\end{array}$ & 15 & 29 & 21 \\
\hline Unclear & 1 & 18 & 120 \\
\hline
\end{tabular}

*18 papers involved stakeholders at both setting scope/review questions and interpreting results after review completion; 3 were judged as 'green', 11 as 'amber' and 4 as 'red' 


\begin{tabular}{|l|l|l|l|}
\hline & Patients / carers involved & $\begin{array}{c}\text { No patients / carers } \\
\text { involved }\end{array}$ & Unclear \\
\hline $\begin{array}{l}\text { 1. setting scope / review } \\
\text { questions }\end{array}$ & & & \\
\hline $\begin{array}{l}\text { 2. interpreting results after } \\
\text { review completion }\end{array}$ & & & \\
\hline $\begin{array}{l}\text { 3. throughout/within the } \\
\text { review process }\end{array}$ & & & \\
\hline unclear & & & \\
\hline
\end{tabular}

\footnotetext{
Key:

Green categorisation for comprehensiveness

Amber categorisation for comprehensiveness

Red categorisation for comprehensiveness
}

Bubbles, and segments, are scaled relative to the number of papers.

Fig. 2 Bubble plot illustrating proportion of papers in which patients/carers were included, the stage of the review process at which people were involved and the comprehensiveness of the description of the method of involvement

\section{People involved}

Seventy-eight percent of the systematic reviews involved patients, carers or family members, while in one $(3 \%)$, the people involved were peer support workers. In $19 \%$ of systematic reviews, the only people involved were professionals or academic experts, although one of these [56] aimed to recruit patient representatives, but failed to do so. Where there were face-to-face meetings, the number of stakeholders involved ranged from 2 to 27; where there were one-off events, often advertised as open to the general public, the numbers of stakeholders involved ranged from 15 to 81 ; where involvement did not require a face-to-face meeting, for example using an electronic Delphi or survey, the numbers invited ranged from 29 to 340 (see Table 6).

\section{Geographical location (from which stakeholders were recruited)}

The majority of the involvement occurred in the UK, with two thirds (66\%) of papers describing UK-based activities. Of the remaining 34\%, 2 recruited people from across Europe, 3 were carried out in Canada, 3 in the Netherlands and 1 in Australia, USA and Spain.

\section{How people were recruited}

For $69 \%(22 / 32)$ of the systematic reviews, people were personally invited to be involved. This involved personal invitations to known people (in 12/22; [29, 31, 39, 41$44,48,54,55,57])$; personal invitations to an existing group or groups (in $6 / 22$; [34, 35, 37, 46, 58]); or purposive sampling, using similar methods as sampling for qualitative research (in $4 / 22$; $[32,38,40,56]$ ). For a further $7 / 32$ of the systematic review, involvement opportunities were advertised to the general population, often snowballing information out via target groups and organisations, and anyone who volunteered could get involved [25, 36, 47, 49, 50, 52, 53]. A combination of different recruitment strategies was used for 1 systematic review [33], and the method of recruitment was unclear for 3 systematic reviews [30, 45, 51]. 
Table $\mathbf{5}$ Key characteristics of 'green' systematic reviews

\begin{tabular}{|c|c|c|c|c|c|}
\hline Review & $\begin{array}{l}\text { Geographical } \\
\text { location }\end{array}$ & Type of paper & Review aim/focus & Focus of review* & $\begin{array}{l}\text { Type of } \\
\text { evidence } \\
\text { synthesised }^{* *}\end{array}$ \\
\hline $\begin{array}{l}\text { Bayliss et al. } \\
{[29]}\end{array}$ & $\begin{array}{l}\text { Europe (UK, } \\
\text { Sweden, } \\
\text { Estonia, } \\
\text { Romania) }\end{array}$ & $\begin{array}{l}\text { Description of methods of } \\
\text { involvement (describes results of } \\
\text { questionnaire-based evaluation of the } \\
\text { involvement) }\end{array}$ & $\begin{array}{l}\text { Qualitative meta-synthesis; perceptions } \\
\text { of predictive testing for those at risk of } \\
\text { developing a chronic inflammatory } \\
\text { disease }\end{array}$ & $\begin{array}{l}\text { XIII Diseases of the } \\
\text { musculoskeletal } \\
\text { system and } \\
\text { connective tissue }\end{array}$ & Qualitative \\
\hline $\begin{array}{l}\text { Boelens et al. } \\
{[30]}\end{array}$ & Europe & $\begin{array}{l}\text { Description of methods of } \\
\text { involvement (describes the consensus } \\
\text { process to develop statements and } \\
\text { recommendations to include in a } \\
\text { patient summary) }\end{array}$ & $\begin{array}{l}\text { Patient summary of consensus for colon } \\
\text { and rectal cancer care }\end{array}$ & |l Neoplasms & Unclear \\
\hline $\begin{array}{l}\text { Bond et al. } \\
\text { [53] }\end{array}$ & Australia & $\begin{array}{l}\text { Report of a guideline/ } \\
\text { recommendation }\end{array}$ & $\begin{array}{l}\text { Guidelines; assisting Australians with } \\
\text { mental health problems and financial } \\
\text { difficulties. }\end{array}$ & $\begin{array}{l}\text { V Mental and } \\
\text { behavioural } \\
\text { disorders }\end{array}$ & Mixed \\
\hline $\begin{array}{l}\text { Braye and } \\
\text { Preston-Shoot } \\
\text { [31] }\end{array}$ & UK & $\begin{array}{l}\text { Description of methods of } \\
\text { involvement (researcher's experiences } \\
\text { of involving stakeholders) }\end{array}$ & $\begin{array}{l}\text { Systematic review; learning, teaching } \\
\text { and assessment of law in social work } \\
\text { education }\end{array}$ & Other & Mixed \\
\hline $\begin{array}{l}\text { Bunn et al. } \\
\text { [32] }\end{array}$ & UK & $\begin{array}{l}\text { Description of methods of } \\
\text { involvement (method to contextualise } \\
\text { findings of a review) }\end{array}$ & $\begin{array}{l}\text { Systematic review of qualitative studies; } \\
\text { patient and carer experiences of } \\
\text { diagnosis and treatment of dementia }\end{array}$ & $\begin{array}{l}\text { V Mental and } \\
\text { behavioural } \\
\text { disorders }\end{array}$ & Qualitative \\
\hline $\begin{array}{l}\text { Concannon et } \\
\text { al. [42] }\end{array}$ & USA & Systematic review & $\begin{array}{l}\text { Systematic review; methods of } \\
\text { stakeholder engagement in comparative } \\
\text { effectiveness research and patient- } \\
\text { centred outcomes research }\end{array}$ & Research & Mixed \\
\hline $\begin{array}{l}\text { Coon et al. } \\
{[63]}\end{array}$ & UK & $\begin{array}{l}\text { Description of methods of } \\
\text { involvement (describe and discuss } \\
\text { methods of involvement in } 4 \text { reviews) }\end{array}$ & $\begin{array}{l}\text { Four systematic reviews; } \\
\text { nonpharmacological interventions for } \\
\text { ADHD used in school settings }\end{array}$ & $\begin{array}{l}\text { V Mental and } \\
\text { behavioural } \\
\text { disorders }\end{array}$ & Mixed \\
\hline $\begin{array}{l}\text { Edwards et al. } \\
\text { [43] }\end{array}$ & UK & Systematic review & $\begin{array}{l}\text { Identification, assessment and } \\
\text { management of risk in young people } \\
\text { with complex mental health needs } \\
\text { entering, using and exiting inpatient } \\
\text { child and adolescent mental health } \\
\text { services in the UK }\end{array}$ & $\begin{array}{l}\vee \text { Mental and } \\
\text { behavioural } \\
\text { disorders }\end{array}$ & Mixed \\
\hline $\begin{array}{l}\text { Harris et al. } \\
{[25]}\end{array}$ & UK & $\begin{array}{l}\text { Description of methods of } \\
\text { involvement (describe and discuss } \\
\text { methods of involvement in a realist } \\
\text { review) }\end{array}$ & $\begin{array}{l}\text { Realist review; community-based peer } \\
\text { support }\end{array}$ & $\begin{array}{l}\text { ICHI Functioning } \\
\text { intervention }\end{array}$ & Mixed \\
\hline $\begin{array}{l}\text { Hayden et al. } \\
{[44]}\end{array}$ & Canada & Systematic review & $\begin{array}{l}\text { Rapid knowledge synthesis; } \\
\text { Collaborative Emergency Centres (CECs) }\end{array}$ & $\begin{array}{l}\text { XXI Factors } \\
\text { influencing health } \\
\text { status and contact } \\
\text { with health } \\
\text { services }\end{array}$ & Unclear \\
\hline $\begin{array}{l}\text { Higginson et } \\
\text { al. [45] }\end{array}$ & UK & Systematic review & $\begin{array}{l}\text { Systematic review; design and conduct } \\
\text { of research on end of life care (EoLC) }\end{array}$ & $\begin{array}{l}\text { XXI Factors } \\
\text { influencing health } \\
\text { status and contact } \\
\text { with health } \\
\text { services }\end{array}$ & Mixed \\
\hline $\begin{array}{l}\text { Hyde et al. } \\
{[34]}\end{array}$ & UK & $\begin{array}{l}\text { Description of methods of } \\
\text { involvement }\end{array}$ & $\begin{array}{l}\text { Systematic review and narrative } \\
\text { synthesis; factors affecting shared } \\
\text { decision-making around prescribing an- } \\
\text { algesia for musculoskeletal pain in pri- } \\
\text { mary care consultations }\end{array}$ & $\begin{array}{l}\text { XIII Diseases of the } \\
\text { musculoskeletal } \\
\text { system and } \\
\text { connective tissue }\end{array}$ & Mixed \\
\hline $\begin{array}{l}\text { Jamal et al. } \\
\text { [35] }\end{array}$ & UK & $\begin{array}{l}\text { Description of methods of } \\
\text { involvement }\end{array}$ & $\begin{array}{l}\text { Systematic review; effects of schools and } \\
\text { school environment interventions on } \\
\text { children and young people's health }\end{array}$ & $\begin{array}{l}\text { XXI Factors } \\
\text { influencing health } \\
\text { status and contact } \\
\text { with health } \\
\text { services }\end{array}$ & Mixed \\
\hline Liabo [46] & UK & $\begin{array}{l}\text { Description of methods of } \\
\text { involvement }\end{array}$ & $\begin{array}{l}\text { Systematic review; effectiveness of } \\
\text { interventions that aim to support looked } \\
\text { after children in school }\end{array}$ & $\begin{array}{l}\text { XXI Factors } \\
\text { influencing health } \\
\text { status and contact } \\
\text { with health }\end{array}$ & Mixed \\
\hline
\end{tabular}


Table 5 Key characteristics of 'green' systematic reviews (Continued)

\begin{tabular}{|c|c|c|c|}
\hline Review & $\begin{array}{l}\text { Geographical } \\
\text { location }\end{array}$ & Type of paper & Review aim/focus \\
\hline Liu et al. [47] & UK & Systematic review & $\begin{array}{l}\text { Mixed-methods systematic review; to } \\
\text { identify, appraise and interpret research } \\
\text { on the approaches employed to } \\
\text { maximise the cross-cultural appropriate- } \\
\text { ness and effectiveness of health promo- } \\
\text { tion interventions for smoking cessation, } \\
\text { increasing physical activity and improv- } \\
\text { ing healthy eating for African-, Chinese- } \\
\text { and South Asian-origin populations }\end{array}$ \\
\hline
\end{tabular}

\begin{tabular}{|c|c|c|}
\hline $\begin{array}{l}\text { Martin et al. } \\
{[36]}\end{array}$ & UK & $\begin{array}{l}\text { Description of met } \\
\text { involvement }\end{array}$ \\
\hline $\begin{array}{l}\text { McConachie } \\
\text { et al. [48] }\end{array}$ & UK & Systematic review \\
\hline $\begin{array}{l}\text { McCusker et } \\
\text { al. [49] }\end{array}$ & Canada & Systematic revie \\
\hline $\begin{array}{l}\text { McGinn et al. } \\
\text { [56] }\end{array}$ & Canada & Systematic revi \\
\hline
\end{tabular}

Morgan et al. UK

[58]

$\begin{array}{lll}\begin{array}{l}\text { Oliver et al. UK } \\ \text { [37] } \\ \text { ('correlational' } \\ \text { review) }\end{array} & \begin{array}{l}\text { Description of methods of } \\ \text { involvement }\end{array} \\ \begin{array}{l}\text { Oliver et al. } \\ \text { [37] ('views' } \\ \text { review) }\end{array} & \begin{array}{l}\text { Description of methods of } \\ \text { involvement }\end{array} \\ \begin{array}{l}\text { Oosterkamp } \\ \text { et al. [54] }\end{array} & \text { Netherlands } & \begin{array}{l}\text { Report of a guideline/ } \\ \text { recommendation }\end{array}\end{array}$

Pearson et al. UK [50]

Pollock et al. UK [38]

Rees et al. [51] UK

Saan et al. Netherlands [55] (review 1)
Systematic review recommendation

Systematic review (description of involvement in supplementary file)

Description of methods of involvement

Systematic review
Systematic review; attitudes and preferences toward population screening for dementia

Systematic review; measurement properties of tools used to measure progress and outcomes in children with autistic spectrum disorder (ASD) up to the age of 6 years

Systematic review; collaborative mental health care for depression

Systematic review; users' perspectives of the factors influencing electronic health record (EHR) implementation

Systematic review (quantitative and qualitative evidence); incentive mechanisms of action for smoking cessation in pregnancy and breastfeeding

Systematic review of observational studies (a 'correlational' review); to explore the quantitative relationship between childhood obesity and educational attainment

Systematic review of interview-based and questionnaire-based research of body size

Systematic review; strategies to prevent WSL (white spot lesions) during orthodontic treatment with fixed appliances

Realist review; conditions and actions which lead to the successful implementation of health promotion programmes in schools

Cochrane review; physical rehabilitation approaches for the recovery of function and mobility in people with stroke

Systematic review; barriers to, or facilitators of, HIV-related sexual health for men who have sex with men (MSM) and MSM's perceptions and experiences of sexual health in the light of HIV ('views review'); children's perspectives

$\begin{array}{ll}\text { Focus of review* }^{*} & \begin{array}{l}\text { Type of } \\ \text { evidence } \\ \text { synthesised }\end{array}\end{array}$

services

ICHI Public health Mixed intervention

\section{$\checkmark$ Mental and \\ behavioural \\ disorders}

Mixed

$\checkmark$ Mental and behavioural

disorders

$\checkmark$ Mental and behavioural disorders

XXI Factors influencing health status and contact with health services

XV Pregnancy, Mixed childbirth and the puerperium

ICHI Public health intervention

ICHI Public health

Qualitative intervention

XI Diseases of the digestive system

Quantitative

ICHI Public health Mixed intervention

IX Diseases of the circulatory system

Quantitative I Certain infectious Mixed and parasitic diseases

Qualitative evidence synthesis; needs of victims of crime with regard to helpful and unhelpful reactions of their social 
Table $\mathbf{5}$ Key characteristics of 'green' systematic reviews (Continued)

\begin{tabular}{|c|c|c|c|c|c|}
\hline Review & $\begin{array}{l}\text { Geographical } \\
\text { location }\end{array}$ & Type of paper & Review aim/focus & Focus of review* & $\begin{array}{l}\text { Type of } \\
\text { evidence } \\
\text { synthesised** }\end{array}$ \\
\hline & & & network including volunteer services & & \\
\hline $\begin{array}{l}\text { Saan et al. } \\
\text { [55] (review 2) }\end{array}$ & Netherlands & Other (development of reporting tool) & $\begin{array}{l}\text { Systematic review; concepts, } \\
\text { determinants and outcome measures } \\
\text { used to evaluate self-management } \\
\text { support }\end{array}$ & Other & Unclear \\
\hline $\begin{array}{l}\text { Serrano- } \\
\text { Anguilar et al. } \\
\text { [39] }\end{array}$ & Spain & $\begin{array}{l}\text { Description of methods of } \\
\text { involvement }\end{array}$ & $\begin{array}{l}\text { Systematic review; effectiveness and } \\
\text { safety of treatment alternatives for } \\
\text { patients with degenerative ataxias (DA) }\end{array}$ & $\begin{array}{l}\text { VI Diseases of the } \\
\text { nervous system }\end{array}$ & Unclear \\
\hline $\begin{array}{l}\text { Smith et al. } \\
\text { [52] }\end{array}$ & UK & Systematic review & $\begin{array}{l}\text { 'Multi-methods review'; service user } \\
\text { involvement in nursing, midwifery and } \\
\text { health visiting research }\end{array}$ & Research & Mixed \\
\hline $\begin{array}{l}\text { Stewart and } \\
\text { Oliver [40] }\end{array}$ & UK & $\begin{array}{l}\text { Description of methods of } \\
\text { involvement }\end{array}$ & $\begin{array}{l}\text { Systematic review of reviews; } \\
\text { communication with parents about } \\
\text { newborn bloodspot screening }\end{array}$ & $\begin{array}{l}\text { XV Pregnancy, } \\
\text { childbirth and the } \\
\text { puerperium }\end{array}$ & Mixed \\
\hline Vale et al. [41] & UK & $\begin{array}{l}\text { Description of methods of } \\
\text { involvement }\end{array}$ & $\begin{array}{l}\text { Cochrane review; chemoradiotherapy for } \\
\text { cervical cancer }\end{array}$ & |l Neoplasms & Quantitative \\
\hline
\end{tabular}

Note that within this table there are 32 reviews described, as 2 of the 30 included papers describe 2 reviews, and data has been extracted separately for these at this stage (Oliver et al. [37] 'correlational' review and 'views' review; Saan et al. [55] review 1 and review 2)

*Focus of review categorised as either: Health/disease of focus according to ICD-10 categories; OR, if review was not focused on a specific health topic/disease, then review was categorised as either: Medical or surgical intervention, Public health intervention, Functioning intervention, Research, or Other

**Type of evidence synthesised categorised as qualitative, quantitative, mixed (i.e. both qualitative and quantitative) or unclear

\section{Format of involvement}

The format of involvement comprised direct, face-to-face interaction in $81 \%$ and an electronic Delphi method or survey in $19 \%$ of the systematic reviews. The face-to-face interaction was either in the format of a meeting (53\%; [29, 31, 32, 34, 35, 38, 40$44,46,50,52,55,58])$, a larger workshop or public event $(19 \%$; $[25,36,37,47,49])$ or a combination of both of these (9\%; $[33,45,48])$. In each of the $6 / 32$ systematic reviews which used an electronic Delphi method, there was a specific and focussed aim of stakeholder involvement; in $4 / 32$ [30, 53, 54, 56], this was broadly related to reaching consensus on factors, recommendations or statements arising from the results of the systematic review, and in $2 / 32[39,55]$, this was to reach consensus on the topic or focus of the systematic review.

\section{Amount of involvement}

Where there was direct face-to-face interaction, there could be between 1 and 20 meetings or events. The majority $(83 \%)$ of the 24 reviews providing this information held 4 or less meetings (median 2 meetings), while one held 5 meetings plus 3 public workshops [45]. Three held multiple meetings (12, 15 and 20 respectively by $[25,46,58])$; in each of these three examples, the approach is described as 'participatory'. Where reported, the length of face-to-face meetings varied from $1 \mathrm{~h}$ to $1 / 2$ day. Generally, the Delphi approach involved three rounds of an electronic survey, although in one example after two rounds of Delphi voting there was a direct face-to-face consensus meeting [54].

\section{Ethical approval}

Details of ethical approval were reported for $31 \%$ of systematic reviews; for details, see Table 6. One paper reported that ethical approval was sought but not required [44]. No details relating to ethical approval were provided by the remaining $66 \%$ of papers.

\section{Financial compensation}

Expenses (such as travel, accommodation and care costs for family members) were reported to be paid to people involved in $25 \%$ of systematic reviews; in two, this was expenses only, while in six money or a voucher was provided in addition to expenses (see Table 6). No details relating to financial compensation are reported in the remaining $75 \%$ of systematic reviews.

\section{Tools or method of reporting involvement}

Thirty-four percent of the included papers had a clear method of reporting involvement. Four used some sort of tool, framework or checklist: Concannon et al. [42] developed and used a 7-item question for reporting stakeholder involvement in research, Liabo [46] used a framework for considering impact of involvement, Martin et al. [36] reported an evaluation based on reporting standards within Guidance for Reporting 
Table 6 Summary of data relating to stakeholder involvement in 'green' systematic reviews

\begin{tabular}{|c|c|c|c|c|c|c|}
\hline Review & $\begin{array}{l}\text { Description of } \\
\text { involvement }\end{array}$ & People involved & Method of involvement & $\begin{array}{l}\text { Formal } \\
\text { research } \\
\text { methods }\end{array}$ & Ethical approval? & $\begin{array}{l}\text { Financial } \\
\text { compensation (or } \\
\text { alternative) for } \\
\text { people involved? }\end{array}$ \\
\hline $\begin{array}{l}\text { Bayliss et al. } \\
\text { [29] }\end{array}$ & $\begin{array}{l}\text { 'Patient research } \\
\text { partners' contributed } \\
\text { via teleconference } \\
\text { calls, written (email) } \\
\text { and one face-to-face } \\
\text { meeting. } \\
\text { Teleconferences: } \\
\text { during completion of } \\
\text { searches and paper } \\
\text { selection, to input } \\
\text { into search } \\
\text { By email: } 3 \text { volunteers } \\
\text { helped with coding } \\
\text { framework to } \\
\text { coproduce themes } \\
\text { with researchers } \\
\text { Meeting: invited to } \\
\text { attend a } 90 \text {-min face- } \\
\text { to-face focus session } \\
\text { at an annual meeting }\end{array}$ & $\begin{array}{l}\text { Women with } \\
\text { rheumatoid arthritis } \\
(n=8) \text {; all with } \\
\text { understanding of the } \\
\text { research process }\end{array}$ & $\begin{array}{l}\text { 'Patient research } \\
\text { partners'-teleconferences, } \\
\text { emails and invitation to } \\
\text { one 90-min meeting }\end{array}$ & - & $\begin{array}{l}\text { No information } \\
\text { provided }\end{array}$ & $\begin{array}{l}\text { No information } \\
\text { provided }\end{array}$ \\
\hline $\begin{array}{l}\text { Boelens et al. } \\
\text { [30] }\end{array}$ & $\begin{array}{l}\text { Experts participated } \\
\text { in three web-based } \\
\text { online voting rounds, } \\
\text { discussion and lec- } \\
\text { tures at a conference. } \\
\text { Patients and patient } \\
\text { representatives were } \\
\text { involved in the } \\
\text { Delphi and had a role } \\
\text { in developing a } \\
\text { patient summary and } \\
\text { future testing and } \\
\text { implementation of } \\
\text { this patient version. } \\
\text { Drafts of the patient } \\
\text { summary were } \\
\text { circulated by email, } \\
\text { and comments } \\
\text { invited. }\end{array}$ & $\begin{array}{l}\text { 'Experts' } \\
\text { (professionals). } \\
\text { People who were } \\
\text { colon or rectal cancer } \\
\text { survivors and } \\
\text { representatives of this } \\
\text { group. }\end{array}$ & $\begin{array}{l}\text { Delphi approach (online, } 3 \\
\text { rounds) } \\
\text { 'In the Delphi online voting } \\
\text { process, } 32 \text { delegates were } \\
\text { able to vote. Patient } \\
\text { representatives had one } \\
\text { vote. It is not known how } \\
\text { many patients attended } \\
\text { the meeting.' }\end{array}$ & $\begin{array}{l}\text { Delphi } \\
\text { approach }\end{array}$ & $\begin{array}{l}\text { No information } \\
\text { provided }\end{array}$ & $\begin{array}{l}\text { No information } \\
\text { provided }\end{array}$ \\
\hline $\begin{array}{l}\text { Bond et al. } \\
\text { [53] }\end{array}$ & $\begin{array}{l}\text { Statements arising } \\
\text { from a systematic } \\
\text { review were used to } \\
\text { form a questionnaire } \\
\text { that was } \\
\text { administered to the } \\
\text { expert panels via } \\
\text { SurveyMonkey. The } \\
\text { panel members were } \\
\text { asked to rate each of } \\
\text { the statements, using } \\
\text { a } 5 \text {-point scale, ac- } \\
\text { cording to whether } \\
\text { or not they thought } \\
\text { the statement should } \\
\text { be included in the } \\
\text { guidelines. }\end{array}$ & $\begin{array}{l}\text { Five expert panels: } \\
\text { financial counsellors, } \\
\text { financial institution } \\
\text { staff, mental health } \\
\text { professionals, mental } \\
\text { health consumer } \\
\text { advocates and carer } \\
\text { advocates. All } \\
\text { panellists had to be } \\
18 \text { years or older, } \\
\text { living in Australia, and } \\
\text { have either } \\
\text { professional or } \\
\text { personal experience } \\
\text { with mental health } \\
\text { problems and } \\
\text { financial difficulties. }\end{array}$ & $\begin{array}{l}\text { Delphi approach (online, } 3 \\
\text { rounds) } \\
\text { (340 participants invited; } \\
214 \text { completed round 1, } \\
170 \text { completed round 2, } \\
162 \text { completed round 3) }\end{array}$ & $\begin{array}{l}\text { Delphi } \\
\text { approach }\end{array}$ & $\begin{array}{l}\text { Ethical approval } \\
\text { granted. }\end{array}$ & $\begin{array}{l}\text { No information } \\
\text { provided }\end{array}$ \\
\hline $\begin{array}{l}\text { Braye and } \\
\text { Preston-Shoot } \\
\text { [31] }\end{array}$ & $\begin{array}{l}\text { The first meeting } \\
\text { aimed to seek views } \\
\text { on the content and } \\
\text { process of the study, } \\
\text { finalising the research } \\
\text { questions and } \\
\text { concluding the } \\
\text { protocol, and to }\end{array}$ & $\begin{array}{l}\text { Service users and } \\
\text { carers }(n=15) \\
\text { professionals }(n=16)\end{array}$ & $\begin{array}{l}\text { Two face-to-face meetings. } \\
\text { Information was sent out } \\
\text { prior to meetings, } \\
\text { introductory presentation. }\end{array}$ & - & $\begin{array}{l}\text { No information } \\
\text { provided }\end{array}$ & $\begin{array}{l}\text { In addition to } \\
\text { researcher time to } \\
\text { undertake these } \\
\text { negotiations, } \\
\text { money was also } \\
\text { set aside to meet } \\
\text { the costs of travel } \\
\text { and special }\end{array}$ \\
\hline
\end{tabular}


Table 6 Summary of data relating to stakeholder involvement in 'green' systematic reviews (Continued)

\begin{tabular}{|c|c|c|c|c|c|c|}
\hline Review & $\begin{array}{l}\text { Description of } \\
\text { involvement }\end{array}$ & People involved & Method of involvement & $\begin{array}{l}\text { Formal } \\
\text { research } \\
\text { methods }\end{array}$ & Ethical approval? & $\begin{array}{l}\text { Financial } \\
\text { compensation (or } \\
\text { alternative) for } \\
\text { people involved? }\end{array}$ \\
\hline & $\begin{array}{l}\text { explore and consider } \\
\text { participants } \\
\text { perspectives around } \\
\text { the topic. The second } \\
\text { meeting aimed to } \\
\text { present and consider } \\
\text { emerging findings } \\
\text { and agree } \\
\text { recommendations for } \\
\text { the final report, and } \\
\text { to consider the } \\
\text { broader implications. }\end{array}$ & & & & & $\begin{array}{l}\text { transport, } \\
\text { accommodation } \\
\text { and fees related } \\
\text { to attendance........ } \\
\text {. It was self- } \\
\text { evident here that } \\
\text { individuals, or } \\
\text { their organisa- } \\
\text { tions, should be } \\
\text { paid for their } \\
\text { time, immediately } \\
\text { in cash when } \\
\text { required. }\end{array}$ \\
\hline $\begin{array}{l}\text { Bunn et al. } \\
\text { [32] }\end{array}$ & $\begin{array}{l}\text { Focus groups and } \\
\text { interviews with key } \\
\text { stakeholders. } \\
\text { Involvement occurred } \\
\text { after completion of } \\
\text { the systematic review, } \\
\text { in order to confirm } \\
\text { the key themes from } \\
\text { the review. }\end{array}$ & $\begin{array}{l}27 \text { participants (three } \\
\text { people with } \\
\text { dementia, } 12 \text { carers, } \\
\text { six dementia service } \\
\text { providers and five } \\
\text { older people without } \\
\text { dementia). } \\
\text { Purposive sampling } \\
\text { approach to } \\
\text { recruitment. }\end{array}$ & $\begin{array}{l}\text { Four focus groups and } \\
\text { three interviews }\end{array}$ & $\begin{array}{l}\text { Focus groups, } \\
\text { interviews }\end{array}$ & $\begin{array}{l}\text { Ethical approval } \\
\text { was obtained } \\
\text { from NRES } \\
\text { Committee East } \\
\text { of England. REC } \\
\text { reference 10/ } \\
\text { H0302/19. }\end{array}$ & $\begin{array}{l}\text { Participants were } \\
\text { given a } £ 10 \\
\text { voucher in } \\
\text { appreciation of } \\
\text { their time, and } \\
\text { their travel } \\
\text { expenses were } \\
\text { reimbursed. }\end{array}$ \\
\hline $\begin{array}{l}\text { Concannon et } \\
\text { al. [42] }\end{array}$ & $\begin{array}{l}\text { Two meetings at } \\
\text { different stages in the } \\
\text { review process. } \\
\text { Meeting } 1 \text { aimed at } \\
\text { confirming the } \\
\text { research questions } \\
\text { and study design. } \\
\text { Meeting } 2 \text { to review } \\
\text { preliminary results. } \\
\text { Group members also } \\
\text { participated by email } \\
\text { and phone, } \\
\text { commenting on } \\
\text { tables, figures and } \\
\text { manuscript drafts, } \\
\text { and were asked to } \\
\text { assist in } \\
\text { dissemination. } \\
\text { In addition, } 3 \text { people } \\
(2 \text { patients) } \\
\text { contributed to review } \\
\text { the planning stages. }\end{array}$ & $\begin{array}{l}\text { Consumers, } \\
\text { professionals, } \\
\text { researchers }(n=7)\end{array}$ & $\begin{array}{l}\text { Two face-to-face meetings. } \\
\text { Email and phone } \\
\text { communication } \\
\text { throughout the review. }\end{array}$ & - & $\begin{array}{l}\text { No information } \\
\text { provided }\end{array}$ & $\begin{array}{l}\text { No information } \\
\text { provided }\end{array}$ \\
\hline $\begin{array}{l}\text { Coon et al. } \\
\text { [63] }\end{array}$ & $\begin{array}{l}\text { An Expert Advisory } \\
\text { group-involved } \\
\text { throughout the } \\
\text { project, including } \\
\text { commenting on the } \\
\text { protocol, editing draft } \\
\text { chapters and } \\
\text { responding to ad hoc } \\
\text { questions. } \\
\text { In addition, a series of } \\
\text { four events were } \\
\text { held: Event } 1 \text { aimed }\end{array}$ & $\begin{array}{l}\text { Expert advisory } \\
\text { group_academics, } \\
\text { charity } \\
\text { representatives, } \\
\text { professionals. } \\
\text { Four events: Event } 1 \\
(n=15), \text { parents, } \\
\text { carers, professionals, } \\
\text { researchers. Event } 2 \\
(n=20), \text { professionals. } \\
\text { Event } 3 \text { ( } n=25) \text {, } \\
\text { parents and young }\end{array}$ & $\begin{array}{l}\text { Expert advisory group. } \\
\text { Four events. }\end{array}$ & - & $\begin{array}{l}\text { No information } \\
\text { provided }\end{array}$ & $\begin{array}{l}\text { No information } \\
\text { provided }\end{array}$ \\
\hline
\end{tabular}


Table 6 Summary of data relating to stakeholder involvement in 'green' systematic reviews (Continued)

\begin{tabular}{|c|c|c|c|c|c|c|}
\hline Review & $\begin{array}{l}\text { Description of } \\
\text { involvement }\end{array}$ & People involved & Method of involvement & $\begin{array}{l}\text { Formal } \\
\text { research } \\
\text { methods }\end{array}$ & Ethical approval? & $\begin{array}{l}\text { Financial } \\
\text { compensation (or } \\
\text { alternative) for } \\
\text { people involved? }\end{array}$ \\
\hline & $\begin{array}{l}\text { to share information } \\
\text { and explore } \\
\text { experiences. Events } 2 \\
\text { and } 3 \text { aimed to } \\
\text { explore interim } \\
\text { findings of the } \\
\text { review. Event } 4 \\
\text { disseminated } \\
\text { findings. }\end{array}$ & $\begin{array}{l}\text { people. Event } 4 \text { ( } n= \\
60) \text {, parents, } \\
\text { professionals, policy } \\
\text { makers. }\end{array}$ & & & & \\
\hline $\begin{array}{l}\text { Edwards et al. } \\
\text { [43] }\end{array}$ & $\begin{array}{l}\text { Individual } \\
\text { interviews_-aimed at } \\
\text { identifying topics for } \\
\text { review to focus on. } \\
\text { Meeting - descriptive } \\
\text { maps from initial } \\
\text { scoping review/ } \\
\text { mapping exercise } \\
\text { were presented. } \\
\text { Informed by the } \\
\text { principles of nominal } \\
\text { group technique, } \\
\text { participants } \\
\text { generated } \\
\text { independent lists of } \\
\text { important topics, } \\
\text { which were collated } \\
\text { and displayed. } \\
\text { Individual participants } \\
\text { then ranked, in } \\
\text { writing, their personal } \\
\text { priorities from the list. }\end{array}$ & $\begin{array}{l}\text { Individual interviews } \\
(n=6) \text {, with young } \\
\text { people (patients) or } \\
\text { their carers. } \\
\text { Face-to-face } \\
\text { meeting-health } \\
\text { professionals, young } \\
\text { people, charity } \\
\text { representative }(n=7) \text {, } \\
\text { plus research team }(n \\
=7)\end{array}$ & $\begin{array}{l}\text { Two methods: } \\
\text { 1) Individual interviews } \\
\text { 2) Face-to-face meeting }\end{array}$ & $\begin{array}{l}\text { Consensus } \\
\text { decision- } \\
\text { making tech- } \\
\text { niques: nom- } \\
\text { inal group } \\
\text { technique }\end{array}$ & $\begin{array}{l}\text { No information } \\
\text { provided }\end{array}$ & $\begin{array}{l}\text { No information } \\
\text { provided }\end{array}$ \\
\hline $\begin{array}{l}\text { Harris et al. } \\
{[25]}\end{array}$ & $\begin{array}{l}\text { Five 'cross- } \\
\text { organisation' events } \\
\text { and seven 'within- } \\
\text { organisation' events. } \\
\text { Also email discussions } \\
\text { and opportunistic } \\
\text { contact with } \\
\text { researchers. } \\
\text { Recruitment to the } \\
\text { advisory network } \\
\text { took place } \\
\text { throughout the } \\
\text { review, and different } \\
\text { individuals had } \\
\text { different levels of } \\
\text { involvement, and at } \\
\text { different stages. Some } \\
\text { members contributed } \\
\text { on multiple occasions } \\
\text { and others only on a } \\
\text { single occasion. }\end{array}$ & $\begin{array}{l}\text { 'Advisory } \\
\text { network'—salaried } \\
\text { workers, health } \\
\text { trainers, volunteer } \\
\text { health champions } \\
\text { and programme } \\
\text { coordinators with } \\
\text { expertise in using } \\
\text { peer support, and } \\
\text { people who had } \\
\text { originally received } \\
\text { support before going } \\
\text { on to become a peer } \\
\text { support worker. }\end{array}$ & $\begin{array}{l}\text { Total of } 12 \text { meetings } \\
\text { (approximately } 240 \text { face-to- } \\
\text { face contacts with around } \\
120 \text { participants) } \\
\text { Format-various, including } \\
\text { use of notes, flip charts, } \\
\text { audio recording, post-it } \\
\text { notes }\end{array}$ & $\begin{array}{l}\text { Participatory } \\
\text { approaches }\end{array}$ & $\begin{array}{l}\text { No information } \\
\text { provided }\end{array}$ & $\begin{array}{l}\text { No information } \\
\text { provided }\end{array}$ \\
\hline $\begin{array}{l}\text { Hayden et al. } \\
{[44]}\end{array}$ & $\begin{array}{l}\text { Workshop } 1=\text { The } \\
\text { goals of the } \\
\text { stakeholder workshop } \\
\text { were to discuss } \\
\text { methods for evidence } \\
\text { synthesis in general; }\end{array}$ & $\begin{array}{l}\text { Selected local } \\
\text { stakeholders }(n=19) \\
\text { (professionals; no } \\
\text { consumers involved) }\end{array}$ & $\begin{array}{l}\text { Group meetings (2) (half } \\
\text { day). Voting for } \\
\text { prioritisation. } \\
\text { Format-activities and } \\
\text { small group discussions to } \\
\text { engage attendees, to }\end{array}$ & - & $\begin{array}{l}\text { No information } \\
\text { provided }\end{array}$ & $\begin{array}{l}\text { No information } \\
\text { provided }\end{array}$ \\
\hline
\end{tabular}


Table 6 Summary of data relating to stakeholder involvement in 'green' systematic reviews (Continued)

\begin{tabular}{|c|c|c|c|c|c|c|}
\hline Review & $\begin{array}{l}\text { Description of } \\
\text { involvement }\end{array}$ & People involved & Method of involvement & $\begin{array}{l}\text { Formal } \\
\text { research } \\
\text { methods }\end{array}$ & Ethical approval? & $\begin{array}{l}\text { Financial } \\
\text { compensation (or } \\
\text { alternative) for } \\
\text { people involved? }\end{array}$ \\
\hline & $\begin{array}{l}\text { to discuss the } \\
\text { objectives and } \\
\text { approach of our } \\
\text { specific project; to } \\
\text { refine definitions and } \\
\text { priorities within the } \\
\text { project; and to } \\
\text { discuss key findings, } \\
\text { key messages, and } \\
\text { dissemination plans. } \\
\text { Workshop } 2 \text { = Key } \\
\text { messages and the } \\
\text { data tables were } \\
\text { discussed at a second } \\
\text { stakeholder } \\
\text { workshop. }\end{array}$ & & $\begin{array}{l}\text { encourage discussion, and } \\
\text { to reach consensus. }\end{array}$ & & & \\
\hline $\begin{array}{l}\text { Higginson et } \\
\text { al. [45] }\end{array}$ & $\begin{array}{l}\text { 'Transparent expert } \\
\text { consultations (TEC)' } \\
\text { involving consensus } \\
\text { methods of nominal } \\
\text { group and online } \\
\text { voting, and } \\
\text { stakeholder } \\
\text { workshops. }\end{array}$ & $\begin{array}{l}\text { Panel of experts in } \\
\text { trials, quantitative, } \\
\text { qualitative and mixed- } \\
\text { method research, } \\
\text { within and outside } \\
\text { palliative care, pa- } \\
\text { tients/consumers, ser- } \\
\text { vice providers, } \\
\text { clinicians, commis- } \\
\text { sioners, national pol- } \\
\text { icy makers and } \\
\text { voluntary sector } \\
\text { representatives }\end{array}$ & $\begin{array}{l}\text { Transparent Expert } \\
\text { Consultation ( } 5 \text { meetings). } \\
3 \text { workshops }-2 \text { with } \\
\text { patients/consumers, } 1 \text { with } \\
\text { clinicians/policy makers }\end{array}$ & $\begin{array}{l}\text { Transparent } \\
\text { Expert } \\
\text { Consultation } \\
\text { (incorporates } \\
\text { NGT) }\end{array}$ & $\begin{array}{l}\text { Ethics } \\
\text { The research } \\
\text { ethics committee } \\
\text { of the University } \\
\text { of Manchester } \\
\text { (reference } \\
\text { number 10328) } \\
\text { approved the TEC } \\
\text { component of } \\
\text { MORECare. All } \\
\text { TEC participants } \\
\text { gave written } \\
\text { consent. }\end{array}$ & $\begin{array}{l}\text { No information } \\
\text { provided }\end{array}$ \\
\hline $\begin{array}{l}\text { Hyde et al. } \\
{[34]}\end{array}$ & $\begin{array}{l}\text { Three meetings at } \\
\text { different stages in the } \\
\text { review process. } \\
\text { Meeting } 1 \text { took place } \\
\text { during the protocol } \\
\text { design stage and } \\
\text { aimed at refining the } \\
\text { scope of the review. } \\
\text { Meeting } 2 \text { took place } \\
\text { at the review } \\
\text { preliminary findings } \\
\text { stage, aimed at } \\
\text { interpreting the } \\
\text { results and planning } \\
\text { the dissemination. } \\
\text { Meeting } 3 \text { took place } \\
\text { at the writing up } \\
\text { stage, aimed at } \\
\text { agreeing final results } \\
\text { and planning how to } \\
\text { share results. }\end{array}$ & $\begin{array}{l}\text { Patients }(n=5), \\
\text { members of an } \\
\text { established patient } \\
\text { research user group } \\
\text { (patients with } \\
\text { musculoskeletal } \\
\text { conditions) }\end{array}$ & $\begin{array}{l}\text { Each face-to-face meeting } \\
\text { was } 3 \mathrm{~h} \text {. } \\
\text { Format of meetings were a } \\
\text { mixture of presentations } \\
\text { with discussion, and using } \\
\text { 'small group techniques' }\end{array}$ & - & $\begin{array}{l}\text { No information } \\
\text { provided }\end{array}$ & $\begin{array}{l}\text { No information } \\
\text { provided }\end{array}$ \\
\hline $\begin{array}{l}\text { Jamal et al. } \\
\text { [35] }\end{array}$ & $\begin{array}{l}\text { Meeting 1-aimed at } \\
\text { informing developed } \\
\text { of review questions. } \\
\text { Discussion around } \\
\text { key terms and } \\
\text { perspectives of } \\
\text { potential } \\
\text { interventions. } \\
\text { Researchers used data } \\
\text { from meeting to } \\
\text { generate topics. } \\
\text { Meeting 2-aimed at } \\
\text { prioritising topics. }\end{array}$ & $\begin{array}{l}\text { Young people ( } n=13 \\
\text { for meeting 1, and } n \\
=13 \text { for meeting } 2) \text {, } \\
\text { from an existing } \\
\text { young people's public } \\
\text { involvement in } \\
\text { research group (the } \\
\text { existing group had } 25 \\
\text { members, who were } \\
\text { recruited via } \\
\text { advertisements. The } \\
\text { group met monthly). }\end{array}$ & $\begin{array}{l}\text { Face-to-face meetings } \\
\text { Meetings were } 1 \mathrm{~h} \text {. } \\
\text { Meetings involved short } \\
\text { presentations and group } \\
\text { discussion. } \\
\text { Meetings were } \\
\text { 'supplemented with an } \\
\text { online discussion forum'. } \\
\text { Meeting } 1 \text { and online } \\
\text { discussion forum } \\
\text { generated list of health } \\
\text { topics. Meeting } 2 \text { agreed a } \\
\text { final list and voted }\end{array}$ & $\begin{array}{l}\text { Consensus } \\
\text { decision- } \\
\text { making tech- } \\
\text { niques: vot- } \\
\text { ing/ranking }\end{array}$ & $\begin{array}{l}\text { No information } \\
\text { provided }\end{array}$ & $\begin{array}{l}\text { Members were not } \\
\text { rewarded directly } \\
\text { from researchers. } \\
\text { However, they } \\
\text { received } £ 15 \\
\text { vouchers for their } \\
\text { monthly } \\
\text { participation (not } \\
\text { specific to this } \\
\text { research project), } \\
\text { had food and } \\
\text { transport provided } \\
\text { and were eligible }\end{array}$ \\
\hline
\end{tabular}


Table 6 Summary of data relating to stakeholder involvement in 'green' systematic reviews (Continued)

\begin{tabular}{|c|c|c|c|c|c|c|}
\hline Review & $\begin{array}{l}\text { Description of } \\
\text { involvement }\end{array}$ & People involved & Method of involvement & $\begin{array}{l}\text { Formal } \\
\text { research } \\
\text { methods }\end{array}$ & Ethical approval? & $\begin{array}{l}\text { Financial } \\
\text { compensation (or } \\
\text { alternative) for } \\
\text { people involved? }\end{array}$ \\
\hline & $\begin{array}{l}\text { Discussion around list } \\
\text { of topics generated } \\
\text { from meeting 1, } \\
\text { followed by voting } \\
\text { for topics considered } \\
\text { most important for } \\
\text { systematic review. } \\
\text { Five priority } \\
\text { systematic reviews } \\
\text { were then carried out } \\
\text { by the researchers. }\end{array}$ & & individually to prioritise. & & & $\begin{array}{l}\text { for an annual } \\
\text { residential } \\
\text { teambuilding } \\
\text { activity. }\end{array}$ \\
\hline Liabo [46] & $\begin{array}{l}\text { A participatory } \\
\text { approach was used } \\
\text { to involve a group of } \\
\text { young people in all } \\
\text { stages of a review. }\end{array}$ & $\begin{array}{l}\text { Young people (total } \\
\text { of } 20 \text { people across } \\
\text { all meetings; } 5 \text { people } \\
\text { only came to } 1 \\
\text { meeting, others to } \\
\text { multiple meetings; } 2 \\
\text { came to all meetings). } \\
\text { Target group was } \\
\text { young people (up to } \\
\text { age of } 25 \text { ) with } \\
\text { experience of being } \\
\text { in care. }\end{array}$ & 20 review meetings & $\begin{array}{l}\text { 'Participatory } \\
\text { methods' }\end{array}$ & $\begin{array}{l}\text { The study was } \\
\text { granted ethical } \\
\text { approval by the } \\
\text { Institute of } \\
\text { Education ethics } \\
\text { committee } \\
\text { (application } \\
\text { number FCH 62) } \\
\text { in November } \\
2007 \text {. }\end{array}$ & $\begin{array}{l}\text { This study adapted } \\
\text { the payment } \\
\text { regulations } \\
\text { operated by PAS, } \\
\text { which was a fixed } \\
\text { amount per hour, } \\
\text { specified for } \\
\text { meetings, training } \\
\text { (half of meetings) } \\
\text { and presentations } \\
\text { (higher than } \\
\text { meetings). }\end{array}$ \\
\hline Liu et al. [47] & $\begin{array}{l}\text { User engagement } \\
\text { was undertaken } \\
\text { throughout our } \\
\text { project through the } \\
\text { inclusion of lay } \\
\text { members on our } \\
\text { Independent Project } \\
\text { Steering Committee; } \\
\text { in addition, we held } \\
\text { two user conferences, } \\
\text { one to launch the } \\
\text { study and one to } \\
\text { share and discuss our } \\
\text { preliminary findings. }\end{array}$ & $\begin{array}{l}\text { A total of } 81 \\
\text { delegates attended } \\
\text { the first conference, } \\
\text { and } 71 \text { the second } \\
\text { conference, from a } \\
\text { wide variety of } \\
\text { stakeholder } \\
\text { organisations. }\end{array}$ & $\begin{array}{l}\text { Independent Project } \\
\text { Steering Committee } \\
\text { Two meetings: } \\
\text { 1. To obtain feedback on } \\
\text { the research proposal and } \\
\text { methods } \\
\text { 2. To present and discuss } \\
\text { preliminary findings }\end{array}$ & - & $\begin{array}{l}\text { Ethical } \\
\text { arrangements } \\
\text { outlined in } \\
\text { protocol, but } \\
\text { unclear if formal } \\
\text { ethical approval } \\
\text { applied for or } \\
\text { granted }\end{array}$ & $\begin{array}{l}\text { No information } \\
\text { provided }\end{array}$ \\
\hline $\begin{array}{l}\text { Martin et al. } \\
{[36]}\end{array}$ & $\begin{array}{l}\text { A PPI (patient and } \\
\text { public involvement) } \\
\text { event was organised } \\
\text { to facilitate members } \\
\text { of the public in the } \\
\text { East of England to } \\
\text { talk about their views } \\
\text { on population } \\
\text { screening for } \\
\text { dementia. The aim } \\
\text { was to contextualise } \\
\text { the findings of a } \\
\text { systematic review for } \\
\text { a British audience. }\end{array}$ & $\begin{array}{l}\text { Purposive approach } \\
\text { (50 invited, } 36 \\
\text { attended) }\end{array}$ & $\begin{array}{l}\text { Meeting ( } 1 \text { all day public } \\
\text { event). Held during the } \\
\text { final stages of the } \\
\text { systematic review }\end{array}$ & $\begin{array}{l}\text { 'Quasi-focus } \\
\text { group format' }\end{array}$ & $\begin{array}{l}\text { No information } \\
\text { provided }\end{array}$ & $\begin{array}{l}\text { In recognition of } \\
\text { participants' time } \\
\text { and to mitigate } \\
\text { the risk of } \\
\text { participant } \\
\text { dropout, a fixed } \\
\text { monetary } \\
\text { honorarium of } £ 80 \\
\text { was offered and } \\
\text { reminder calls } \\
\text { were made in } \\
\text { advance of the } \\
\text { event. Costs for } \\
\text { supportive care } \\
\text { were provided to } \\
\text { partners if they } \\
\text { attended without } \\
\text { their care } \\
\text { recipients, and } \\
\text { travel costs }\end{array}$ \\
\hline $\begin{array}{l}\text { McConachie } \\
\text { et al. [48] }\end{array}$ & $\begin{array}{l}\text { A 'multifaceted } \\
\text { approach to } \\
\text { consultation', } \\
\text { including (1) } \\
\text { consultation with } \\
\text { young people with }\end{array}$ & $\begin{array}{l}\text { People with ASD_12 } \\
\text { young people and } 8 \\
\text { adults responded. } \\
\text { Health } \\
\text { professionals_-838 } \\
\text { survey respondents }\end{array}$ & $\begin{array}{l}\text { Methods included } \\
\text { meetings, survey and } \\
\text { emails. }\end{array}$ & $\begin{array}{l}\text { Q-sort for } \\
\text { rating } \\
\text { agreement } \\
\text { with } \\
\text { outcomes }\end{array}$ & $\begin{array}{l}\text { No information } \\
\text { provided }\end{array}$ & $\begin{array}{l}\text { Young people: } \\
\text { 'Each respondent } \\
\text { was given a } \\
\text { shopping voucher } \\
\text { in } \\
\text { acknowledgement }\end{array}$ \\
\hline
\end{tabular}


Table 6 Summary of data relating to stakeholder involvement in 'green' systematic reviews (Continued)

\begin{tabular}{|c|c|c|}
\hline Review & $\begin{array}{l}\text { Description of } \\
\text { involvement }\end{array}$ & People involved \\
\hline & $\begin{array}{l}\text { ASD, in groups and } \\
\text { by email; (2) survey of } \\
\text { health professionals; } \\
\text { (3) consultation with } \\
\text { parents-3 meetings } \\
\text { throughout review } \\
\text { process; (4) multiple } \\
\text { stakeholder } \\
\text { discussion day about } \\
\text { the preliminary } \\
\text { conclusions of the } \\
\text { review. }\end{array}$ & $\begin{array}{l}\text { Parents-7 } \\
\text { participated in one or } \\
\text { more meetings } \\
\text { Multiple stakeholder } \\
\text { day-16 people }\end{array}$ \\
\hline $\begin{array}{l}\text { McCusker et } \\
\text { al. [49] }\end{array}$ & $\begin{array}{l}\text { A literature review on } \\
\text { collaborative mental } \\
\text { health care for } \\
\text { depression was } \\
\text { completed and used } \\
\text { to guide discussion at } \\
\text { an interactive } \\
\text { workshop. The } \\
\text { workshop was held } \\
\text { as part of pre- } \\
\text { conference activities } \\
\text { at the June } 2011 \text { Can- } \\
\text { adian Conference on } \\
\text { Collaborative Mental } \\
\text { Health Care in Halifax, } \\
\text { Nova Scotia. }\end{array}$ & $\begin{array}{l}\text { We invited a } \\
\text { spectrum of } \\
\text { stakeholders to } \\
\text { participate, aiming to } \\
\text { have roughly equal } \\
\text { representation of } 4 \\
\text { groups: primary care } \\
\text { providers, mental } \\
\text { health providers, } \\
\text { decision makers and } \\
\text { consumers. }\end{array}$ \\
\hline
\end{tabular}

Workshop $(n=40 ; 9$ members of planning committee and 31 invited stakeholders)

Survey, to rate agreement with themes arising from workshop $(n=21 / 42,50 \%$ response rate)
McGinn et al. A Delphi study [56] among Canadian representatives of actual or potential EHR users to confirm the findings of the systematic review and to prioritise the key barriers and facilitating factors for EHR implementation in Canada.

Morgan et al. As part of a [58] partnership approach professionals $(0$ for a wider project relating to incentive mechanisms for smoking cessation in pregnancy and breastfeeding, 2 mother-and-baby groups were recruited and were coapplicants on the
106 participants: 14 physicians, 30 healthcare professionals, 33 managers, 29 health information patient representatives due to low recruitment).

Members of 2 existing 15 meetings (during

Delphi—3 rounds: 83 participants completed round 1, 69 round 2 and 63 round 3 . project, not just systematic review component). around 12 people). Groups were mother and baby/toddler groups.

Members contributed to interpretation of systematic review findings by providing feedback on a number of vignettes of studies included in the evidence synthesis.

Formal
research
methods

Thematic analysis of workshop discussion

Ethical approval?

Financial

compensation (or alternative) for people involved?

of their

contribution'.

Parents: 'Parents

were given a

financial

acknowledgement

in addition to

travel expenses, to

recognise their

time and expertise

at each

attendance'.

The protocol was approved by the

St Mary's Hospital

No information

Research Ethics

Committee.

Participants

provided oral but

not written

consent to

participate.

Permission was

requested at the

workshop for the

proceedings to

be audio-

recorded and

photographed,

and for the partic-

ipants' names and

affiliations to be

listed in the final

report. As one

person did not

agree to audio re-

cordings, no re-

cordings were

made.

Delphi

approach

Ethics approval

for the study

protocol was

received from the

Research Ethics

Board of the

Centre Hospitalier

Universitaire de

Québec

(approved

January 23, 2009;

ethics number 5-

08-12-06).

'Participatory'

Although the

service user

No information

collaborators

were

independent or

local government

representatives,

rather than NHS

groups, we

considered it

preferable to gain

ethics committee

No information

provided
No inform
provided 
Table 6 Summary of data relating to stakeholder involvement in 'green' systematic reviews (Continued)

\begin{tabular}{|c|c|c|c|c|c|c|}
\hline Review & $\begin{array}{l}\text { Description of } \\
\text { involvement }\end{array}$ & People involved & Method of involvement & $\begin{array}{l}\text { Formal } \\
\text { research } \\
\text { methods }\end{array}$ & Ethical approval? & $\begin{array}{l}\text { Financial } \\
\text { compensation (or } \\
\text { alternative) for } \\
\text { people involved? }\end{array}$ \\
\hline & wider project. & & & & $\begin{array}{l}\text { approval before } \\
\text { active } \\
\text { engagement, } \\
\text { particularly } \\
\text { because the } \\
\text { groups had not } \\
\text { been involved in } \\
\text { research before. }\end{array}$ & \\
\hline $\begin{array}{l}\text { Oliver et al. } \\
\text { [37] } \\
\text { ('correlational' } \\
\text { review) }\end{array}$ & $\begin{array}{l}\text { A one-off workshop/ } \\
\text { meeting with mem- } \\
\text { bers of an existing } \\
\text { group. The workshop } \\
\text { was scripted. Ground } \\
\text { rules were } \\
\text { established. } \\
\text { Literature had been } \\
\text { screened but not } \\
\text { synthesised: } \\
\text { involvement explored } \\
\text { variables and } \\
\text { pathways that had } \\
\text { been examined in the } \\
\text { literature, aiming to } \\
\text { contribute to a } \\
\text { theoretical framework } \\
\text { to help synthesise } \\
\text { study findings. }\end{array}$ & $\begin{array}{l}\text { Young people, aged } \\
12-17 \text { years } \\
\text { (approximately 12) }\end{array}$ & $\begin{array}{l}\text { One meeting }(2.5 \mathrm{~h}) \text {. } \\
\text { Format: discussion, ranking } \\
\text { of themes }\end{array}$ & $\begin{array}{l}\text { Used methods } \\
\text { for ranking of } \\
\text { importance } \\
\text { (stickers and } \\
\text { ranking cards), } \\
\text { but these did } \\
\text { not directly } \\
\text { inform } \\
\text { decision- } \\
\text { making }\end{array}$ & $\begin{array}{l}\text { No information } \\
\text { provided }\end{array}$ & $\begin{array}{l}\text { No information } \\
\text { provided }\end{array}$ \\
\hline $\begin{array}{l}\text { Oliver et al. } \\
\text { [37] ('views' } \\
\text { review) }\end{array}$ & $\begin{array}{l}\text { A one-off workshop/ } \\
\text { meeting with mem- } \\
\text { bers of an existing } \\
\text { group. The workshop } \\
\text { was scripted. Ground } \\
\text { rules were } \\
\text { established. } \\
\text { The synthesis of } \\
\text { literature was almost } \\
\text { complete; the aim of } \\
\text { involvement was to } \\
\text { provide a check on } \\
\text { the credibility of the } \\
\text { synthesis and } \\
\text { develop review } \\
\text { implications. }\end{array}$ & $\begin{array}{l}\text { Young people, aged } \\
12-17 \text { years } \\
\text { (approximately } 12 \text { ) }\end{array}$ & $\begin{array}{l}\text { One meeting }(2.5 \mathrm{~h}) \text {. } \\
\text { Format: discussion, ranking } \\
\text { of themes }\end{array}$ & As above & $\begin{array}{l}\text { No information } \\
\text { provided }\end{array}$ & $\begin{array}{l}\text { No information } \\
\text { provided }\end{array}$ \\
\hline $\begin{array}{l}\text { Oosterkamp } \\
\text { et al. [54] }\end{array}$ & $\begin{array}{l}\text { RAND-e modified } \\
\text { Delphi ( } 2 \text { rounds) } \\
\text { Group (consensus) } \\
\text { meeting } \\
\text { The purpose of the } \\
\text { involvement was to } \\
\text { develop consensus } \\
\text { on statements on the } \\
\text { prevention of WSL } \\
\text { during orthodontic } \\
\text { treatment with fixed } \\
\text { appliances. }\end{array}$ & $\begin{array}{l}\text { The expert panel } \\
\text { comprised } 11 \\
\text { representatives, all } \\
\text { graduated dentists, } \\
\text { from research, } \\
\text { education, } \\
\text { orthodontics, } \\
\text { cariology, general } \\
\text { dentistry and advisory } \\
\text { general dental } \\
\text { practitioners from } \\
\text { health insurance } \\
\text { companies. }\end{array}$ & $\begin{array}{l}\text { RAND-e modified Delphi } \\
\text { procedure (involves } \\
\text { considering patient } \\
\text { vignettes). } \\
\text { Consensus meeting }\end{array}$ & $\begin{array}{l}\text { Delphi } \\
\text { approach }\end{array}$ & $\begin{array}{l}\text { No information } \\
\text { provided }\end{array}$ & $\begin{array}{l}\text { No information } \\
\text { provided }\end{array}$ \\
\hline $\begin{array}{l}\text { Pearson et al. } \\
\text { [50] }\end{array}$ & $\begin{array}{l}\text { Two meetings at } \\
\text { different stages in the }\end{array}$ & $\begin{array}{l}\text { Professionals ( } n= \\
\text { 10)_primary and }\end{array}$ & $\begin{array}{l}\text { Two face-to-face meetings } \\
\text { (length unclear) }\end{array}$ & - & $\begin{array}{l}\text { No information } \\
\text { provided }\end{array}$ & $\begin{array}{l}\text { No information } \\
\text { provided }\end{array}$ \\
\hline
\end{tabular}

Meeting 1 took place level educational-

at the start of the fessionals and senior review and aimed to academics linked to 'sharpen the focus of the review 
Table 6 Summary of data relating to stakeholder involvement in 'green' systematic reviews (Continued)

\begin{tabular}{ll}
\hline Review & $\begin{array}{l}\text { Description of } \\
\text { involvement }\end{array}$ \\
& \\
& the review so that it \\
& would be relevant to \\
& those directly \\
involved in the & implementation'. \\
& Meeting 2 took place \\
& when a draft of the \\
& review was complete, \\
aimed at getting & feedback on this \\
draft.
\end{tabular}

Pollock et al. Three meetings at [38]
Rees et al. [51] An advisory group, which met 3 times during the project. The specific tasks for the group included: - Advising on the most appropriate terminology relevan to the subject area;

- Identifying the literature, particularly unpublished reports;

- Identifying and prioritising a priori outcomes for analysis;

- Informing decisions the review team had to make at key stages of the review;

- Helping to disseminate the work through incorporating its findings into members' respective areas of work, and publicising the review to colleagues and associates.

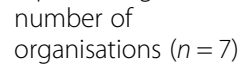

Patients, carers, professionals $(n=13)$

Three face-to-face meetings (half day meetings) Additional contact by email technique

Formal
research
methods

Ethical approval?

Ethical approval?

Financial compensation (or alternative) for people involved?
Researchers/
academics, policy
specialists, voluntary
sector workers, and a
practitioner,
representing a
number of

Researchers/
academics, policy
specialists, voluntary
sector workers, and a
practitioner,
representing a
number of

Researchers/
academics, policy
specialists, voluntary
sector workers, and a
practitioner,
representing a
number of

Researchers/
academics, policy
specialists, voluntary
sector workers, and a
practitioner,
representing a
number of

Researchers/
academics, policy
specialists, voluntary
sector workers, and a
practitioner,
representing a
number of

Researchers/
academics, policy
specialists, voluntary
sector workers, and a
practitioner,
representing a
number of

\section{Meeting 1 aimed to throughout review.}

Three face-to-face meetings, of around $2 \mathrm{~h}$.

Format-meetings were

'semi-informal', involving presentations, discussions and explicit consensus methods (voting)
Consensus decisionmaking techniques: voting

\author{
The project was \\ approved by the \\ Glasgow \\ Caledonian \\ University School \\ of Health and Life \\ Sciences ethics \\ committee \\ (Reference: \\ HLS12/40). \\ We costed for the \\ direct expenses \\ associated with \\ involvement (that \\ is, travel, \\ subsistence), but \\ not for any \\ funding to pay for \\ the time of group \\ members.
}

No information No information provided provided
'A partnership

[55] (review 1) between the
Academic experts ( $n$ =2) 'discussion' Format unclear
No information provided
No information provided 
Table 6 Summary of data relating to stakeholder involvement in 'green' systematic reviews (Continued)

\begin{tabular}{|c|c|c|c|c|c|c|}
\hline Review & $\begin{array}{l}\text { Description of } \\
\text { involvement }\end{array}$ & People involved & Method of involvement & $\begin{array}{l}\text { Formal } \\
\text { research } \\
\text { methods }\end{array}$ & Ethical approval? & $\begin{array}{l}\text { Financial } \\
\text { compensation (or } \\
\text { alternative) for } \\
\text { people involved? }\end{array}$ \\
\hline & $\begin{array}{l}\text { commissioner and } \\
\text { researchers' }\end{array}$ & & & & & \\
\hline $\begin{array}{l}\text { Saan et al. } \\
\text { [55] (review 2) }\end{array}$ & $\begin{array}{l}\text { Participants in an } \\
\text { anonymous online } \\
\text { Delphi process: ' } 39 \\
\text { experts from the } \\
\text { Netherlands ( } 34 \\
\text { researchers and five } \\
\text { policy advisors) were } \\
\text { invited by email. They } \\
\text { were contacted } \\
\text { through the contact } \\
\text { list of a recent expert } \\
\text { meeting on self- } \\
\text { management in the } \\
\text { Netherlands and } \\
\text { through the profes- } \\
\text { sional network of } \\
\text { members of the re- } \\
\text { search group.' }\end{array}$ & $\begin{array}{l}\text { Academic experts ( } 29 \\
\text { invited: } 20 \text { completed } \\
\text { first round of Delphi, } \\
17 \text { second round, } 16 \\
\text { third round) }\end{array}$ & Anonymous online Delphi & $\begin{array}{l}\text { Consensus } \\
\text { decision- } \\
\text { making tech- } \\
\text { niques: Delphi }\end{array}$ & $\begin{array}{l}\text { No information } \\
\text { provided }\end{array}$ & $\begin{array}{l}\text { No information } \\
\text { provided }\end{array}$ \\
\hline $\begin{array}{l}\text { Serrano- } \\
\text { Anguilar et al. } \\
\text { [39] }\end{array}$ & $\begin{array}{l}\text { Three rounds of } \\
\text { electronic Delphi. } \\
\text { Round } 1 \text {-an open } \\
\text { questionnaire to } \\
\text { explore the } \\
\text { treatments used by } \\
\text { patients and } \\
\text { perceived health } \\
\text { problems associated } \\
\text { with their disease. } \\
\text { Round 2-aimed at } \\
\text { prioritising the health } \\
\text { problems identified in } \\
\text { the first round. Round } \\
3 \text {-aimed at reaching } \\
\text { final consensus. }\end{array}$ & $\begin{array}{l}\text { Patients with DA ( } n= \\
\text { 53) }\end{array}$ & $\begin{array}{l}\text { Electronic Delphi ( } 3 \\
\text { rounds) }\end{array}$ & $\begin{array}{l}\text { Consensus } \\
\text { decision- } \\
\text { making tech- } \\
\text { niques: Delphi } \\
\text { method }\end{array}$ & $\begin{array}{l}\text { This study was } \\
\text { approved by the } \\
\text { Ethics Committee } \\
\text { of the Canary } \\
\text { Islands since its } \\
\text { coordination was } \\
\text { carried out by the } \\
\text { Planning and } \\
\text { Evaluation Unit of } \\
\text { the Canary Islands } \\
\text { Health Service }\end{array}$ & $\begin{array}{l}\text { No information } \\
\text { provided }\end{array}$ \\
\hline $\begin{array}{l}\text { Smith et al. } \\
\text { [52] }\end{array}$ & $\begin{array}{l}\text { A 'reference' group } \\
\text { was set up for the } \\
\text { project. There were } 3 \\
\text { face-to-face meetings } \\
\text { at different stages in } \\
\text { the review. Meeting } 1 \\
\text { was aimed at sharing } \\
\text { ideas and agreeing } \\
\text { how the group would } \\
\text { work. Meeting } 2 \text { dis- } \\
\text { cussed the scope and } \\
\text { remit of the review. } \\
\text { Meeting } 3 \text { was aimed } \\
\text { at identifying key } \\
\text { messages from the } \\
\text { findings and planning } \\
\text { dissemination. } \\
\text { Additional } \\
\text { communication } \\
\text { between researchers } \\
\text { and the reference } \\
\text { group occurred by } \\
\text { telephone } \\
\text { conversations, email, } \\
\text { project website and } \\
\text { newsletters. }\end{array}$ & $\begin{array}{l}\text { Service user and carer } \\
\text { advocacy group } \\
\text { members }(n=26)\end{array}$ & $\begin{array}{l}\text { Three face-to-face meet- } \\
\text { ings (length unclear) }\end{array}$ & - & $\begin{array}{l}\text { No information } \\
\text { provided }\end{array}$ & $\begin{array}{l}\text { No information } \\
\text { provided }\end{array}$ \\
\hline Steward and & The wider project aim & 22 parents, with & roup meetings (3), over & - & No information & Paid: \\
\hline
\end{tabular}


Table 6 Summary of data relating to stakeholder involvement in 'green' systematic reviews (Continued)

\begin{tabular}{|c|c|c|c|c|c|c|}
\hline Review & $\begin{array}{l}\text { Description of } \\
\text { involvement }\end{array}$ & People involved & Method of involvement & $\begin{array}{l}\text { Formal } \\
\text { research } \\
\text { methods }\end{array}$ & Ethical approval? & $\begin{array}{l}\text { Financial } \\
\text { compensation (or } \\
\text { alternative) for } \\
\text { people involved? }\end{array}$ \\
\hline Oliver [40] & $\begin{array}{l}\text { was to ensure that } \\
\text { policies and resources } \\
\text { arising from the } \\
\text { systematic review } \\
\text { were relevant to } \\
\text { parents, taking into } \\
\text { account their } \\
\text { experiences and } \\
\text { views. Policy and } \\
\text { resources were } \\
\text { developed by } 12 \\
\text { multi-disciplinary ex- } \\
\text { pert groups. Parents } \\
\text { were included in } \\
\text { these expert groups } \\
\text { to share experiences } \\
\text { and join discussions. }\end{array}$ & $\begin{array}{l}\text { experiences of } \\
\text { newborn screening }\end{array}$ & an 18-month period. & & provided & $\begin{array}{l}\text { - Parents' travel } \\
\text { expenses to and } \\
\text { from meetings } \\
\text { - For coffee at pre- } \\
\text { meetings } \\
\text { - Honoraria for } \\
\text { parents } \\
\text { equivalent to } £ 17 \\
\text { per hour at each } \\
\text { meeting, given in } \\
\text { gift } \\
\text { vouchers: this } \\
\text { came to } £ 75-£ 100 \\
\text { for each meeting } \\
\text { - A fee to } \\
\text { organisations that } \\
\text { assisted with } \\
\text { recruitment, in } \\
\text { recognition of } \\
\text { the support these } \\
\text { organisations } \\
\text { provided to } \\
\text { parents. The fee } \\
\text { was either } £ 8 \text { per } \\
\text { hour of meeting } \\
\text { attended by their } \\
\text { members, or } \\
\text { later, because this } \\
\text { became too } \\
\text { difficult to } \\
\text { administer, a } \\
\text { one-off } £ 50 \text { fee } \\
\text { per parent } \\
\text { recruited. }\end{array}$ \\
\hline Vale et al. [41] & $\begin{array}{l}\text { Patient research } \\
\text { partners had an initial } \\
\text { face-to-face meeting, } \\
\text { then contributed to a } \\
\text { number of review ac- } \\
\text { tivities, including 'pro- } \\
\text { viding feedback on } \\
\text { the detailed informa- } \\
\text { tion folders, helping } \\
\text { to trace contact de- } \\
\text { tails for trial investiga- } \\
\text { tors, learning about } \\
\text { data management } \\
\text { and analysis and con- } \\
\text { tributing to regular } \\
\text { project newsletter' }\end{array}$ & $\begin{array}{l}\text { (1) Reference } \\
\text { group_professionals, } \\
\text { patient/charity } \\
\text { representatives, } \\
\text { patient }(n=7) \\
\text { (2) Patient research } \\
\text { partners - women } \\
\text { who had received } \\
\text { treatment for cervical } \\
\text { cancer }(n=6)\end{array}$ & $\begin{array}{l}\text { 'Patient research } \\
\text { partners'—also } \\
\text { contributing to another } \\
\text { research project-around } 6 \\
\text { meetings/year. Additional } \\
\text { communication via email }\end{array}$ & - & $\begin{array}{l}\text { No information } \\
\text { provided }\end{array}$ & $\begin{array}{l}\text { No information } \\
\text { provided }\end{array}$ \\
\hline
\end{tabular}

Note that within this table there are 32 reviews described, as 2 of the 30 included papers describe 2 reviews, and data has been extracted separately for these at this stage (Oliver et al. [37] 'correlational' review and 'views' review; Saan et al. [55] review 1 and review 2)

Involvement of Patients and the Public (GRIPP) checklist [59] and Saan et al. [55] developed and used a Tool for Recording and Accounting for Stakeholder Involvement (TRASI). Seven specifically reported activities which groups of stakeholders were involved in within a specific section of text, tables or supplementary files $[30,35,37,38,47,50]$. Within the remaining $66 \%$ of systematic reviews, information about methods of involvement was not reported within a particular section, table or file, but was distributed throughout the paper.

\section{Evaluation of the methods of involvement}

None of the 32 studies carried out any formal evaluation of the impact of involving stakeholders; however, $28 \%$ collected data relating to the views and experiences of 
people involved. Of these, four used a questionnaire to elicit the views and experiences of stakeholders [29, 30, $36,41]$; three held a discussion with stakeholders in which they were encouraged to share or reflect on their experiences and perspectives [31, 33, 47]; and two had both a questionnaire and a discussion [38, 44]. In addition, Liabo [46] reported data arising from audio recordings and minutes of all meetings, Hyde et al. [34] described 'impact' within a table, while the reflections of the researchers on the process of involvement were discussed by others $[35,37,40,52]$.

\section{Discussion}

\section{Key findings: evidence-base relating to stakeholder involvement in systematic reviews}

We identified 291 papers describing stakeholder involvement in systematic reviews. Approximately two thirds of published examples describe UK activities, but we found examples from at least 24 countries. Reporting of who was involved, in what ways and at what stage in the review process was generally very poor, and the majority of the papers (59\%) were judged to provide few details and/or an inadequate description of the method or approach of involving stakeholders. Thirty percent of systematic review teams clearly involved patients/carers, but in many cases (41\%), the stakeholders involved health professionals, academic experts or representatives of patient organisations, but not patients or their family members.

We identified 30 papers, describing 32 systematic reviews, which we judged to have sufficiently comprehensive reporting to allow a more in-depth synthesis of methods or approaches to the involvement of stakeholders in systematic review. We have described key features of how stakeholders have been involved in systematic reviews, using data from these 32 examples. However, it was notable that, despite the selection of systematic reviews which were judged to provide a comprehensive description of one or more method of involvement, there was still inadequate (or absence of) reporting of a number of features in which we were interested. For example, the majority of papers did not provide any information relating to ethical approval or financial compensation to the stakeholders involved. A key contributing factor to the poor reporting relating to aspects of how stakeholders were involved may have been the lack of a tool or standardised method for reporting. On the few occasions where a particular tool has been used to support reporting of information relating to involvement, the tool has often been developed specifically by the systematic review authors. In many cases, the method of reporting comprises a written description of the activities in which stakeholders have been involved, but we found inconsistencies in the type of information presented and the location of this information within published papers.

\section{Implications: methods of involving stakeholders in systematic reviews}

The evidence which we have synthesised demonstrates that actively involving stakeholders within systematic reviews is feasible, and can be incorporated into a wide range of different types of systematic review. While there can be considerable variation in how stakeholders are involved, and the types of stakeholders who are involved, and there is currently an absence of evidence to directly inform choices for methods of stakeholder involvement within future reviews, a number of implications can be drawn from our synthesised evidence. In particular, evidence drawn from the 32 examples explored in this review can highlight some of the methodological decisions which may be made when planning stakeholder involvement in future reviews. These include:

- Will people directly affected by the healthcare topic addressed within the systematic review (i.e. individual patients, carers or family members) be involved? Will health professionals, academic experts or representatives from patient organisations be involved?

- How to find people to involve? Within our 32 examples, we found two key methods of recruiting stakeholders to be in systematic reviews; in the majority of our examples, there were personal invitations to known individuals or groups, but in some cases, recruitment occurred through advertising to the general population in order to get stakeholders to volunteer to be involved.

- How will people be involved? Within our 32 examples, two distinct methods of involving people in a systematic review were identified: (i) face-toface meetings or events or (ii) electronic Delphi method. Where there were face-to-face meetings, these could be attended by invited participants only or could be an open event or workshop to which members of the public are invited to attend. Invited participants may only attend a small number (often between 1 and 4) of meetings during the course of a systematic review, but this may be much more where a participatory approach is used.

- How many stakeholders to involve? The current evidence base indicates that the number of stakeholders depends on the way in which they will be involved. Evidence from the 291 papers in our synthesis shows that 1 stakeholder may be a coauthor on a systematic review, 2-10 stakeholders may be members of a steering group, $5-50$ stakeholders may attend face-to-face meetings or focus 
groups and 20-400 stakeholders may participate in Delphi rounds or attend events or conferences.

- Use of research methods? Our examples highlighted that the following research methods have sometimes been incorporated into stakeholder involvement in systematic reviews: focus groups, interviews and a number of consensus decision-making techniques such as Delphi, Nominal Group Technique and voting/ranking processes.

Other issues to consider when planning stakeholder involvement in systematic reviews are whether ethical approval will be required and resources for payment of expenses and any other financial compensation or reward.

Although there is insufficient evidence to directly inform choices relating to who to involve and in what way, the findings arising from the 32 papers identified in this review have been used to produce, in collaboration with Cochrane Training, freely available online learning material and resources [60]. There have been many urgent calls for high-quality training materials, reporting guidelines and examples of best practice to support active stakeholder involvement and to enhance the relevance, usefulness and accessibility of systematic reviews $[2,16,18,33$, 61]; the evidence from this review therefore can arguably currently play a key role in learning and support relating to active stakeholder involvement in systematic reviews.

\section{Implications: reporting stakeholder involvement in systematic reviews}

Recording and reporting of stakeholder involvement is important, both to ensure transparency in relation to the contributions and roles of different stakeholders within the review process and to contribute to the evidence base relating to this field. This scoping review highlights that the current reporting of involvement in systematic reviews is very poor and sometimes absent, and rarely provides a comprehensive description of who was involved and in what way. While there are a number of tools and frameworks which review authors could consider using (e.g. [36, 46, 55]), there is not currently any tool, guidance or recommendations specifically designed to support reporting of involvement within systematic reviews. Generic guidance relating to the reporting of stakeholder involvement in research has recently been updated (GRIPP2, [62]); however, this guidance has not been specifically tested for use with systematic reviews and has lacked international input during development. It is clear that there is an urgent need for improved reporting of involvement of stakeholders in systematic reviews. Such reporting should enhance the ability to develop evidence-based guidance around how to involve stakeholders in systematic reviews, and to explore and evaluate the impact of involvement.

\section{Limitations \\ Identification of relevant systematic reviews and data extraction}

It is unlikely we identified all relevant examples of stakeholder involvement in systematic reviews, as we adopted a pragmatic search approach aimed at efficiency within project time and resource constraints. This was compounded by poor reporting and inconsistent terminology in this area. We believe it is highly likely that there are many systematic reviews where stakeholders played a key role that our methods could not identify. Our decision to exclude titles without abstracts and review protocols at the study selection stage may have introduced publication bias into our results, with a bias toward inclusion of papers published in peer-reviewed journals. Only one review author extracted data from the included studies, and there is the potential that this may have introduced bias and errors in extraction. In an attempt to improve transparency and reduce data extraction errors, we copied and pasted data verbatim from included papers into an electronic data extraction sheet. This is reported in the table of included studies (Additional file 7).

\section{Judgement to identify those with most comprehensive description}

The agreement between independent reviewers when applying the 'comprehensiveness' judgement to a subset of papers indicated that there were disagreements on around $17 \%$ of 'green' categorisations. We did not have the time or resources to have independent judgement on a higher proportion of studies. We are therefore not confident that our subset includes all papers which may provide an adequate description of some parts of the methods of involving people in a review. However, as the aim of this phase was to identify and describe methods of involvement from examples of systematic reviews, the impact of potentially falsely including or excluding a paper from this subset was perceived to be low. We present the included 'green' papers as examples of systematic reviews in which there was involvement of stakeholders and take care to stress that these are examples rather than a comprehensive sample.

Our judgement of the comprehensiveness of the description of the methods was not a judgement of the quality of the involvement methods and only relates to the depth of the description of stakeholder involvement provided in the identified paper. Over half (54\%) of the 291 included papers were reports of a guideline or recommendation, but only 2 of these were judged as 'green' for comprehensiveness of description. A potential explanation for this finding could be that stakeholder involvement is generally a core component of guideline development, but the primary focus of related journal publications is often the key clinical messages and implications, rather than the methods of the guideline, which 
are often fully described elsewhere. A judgement of 'amber' or 'red' for the comprehensiveness of the description of the method of involvement in the published paper is not an indication either that the quality of the methods was poor or that details of methods of stakeholder involvement are not available elsewhere.

\section{Conclusion}

This systematic review summarises evidence relating to the involvement of stakeholders in systematic reviews. We identified a relatively large number (291) of papers reporting stakeholder involvement in systematic reviews, but the quality of reporting was generally very poor. The level of reporting of involvement of stakeholders in systematic reviews, and the inconsistencies in which this is reported, must be improved so that guidance around how people can be involved in systematic reviews can be developed and the impact of involvement explored. This scoping review lends support to calls for high-quality training materials and examples of best practice to support active patient and public involvement and enhance the relevance, usefulness and accessibility of systematic reviews $[2,16,18,61,63]$. We identified a subset of 30 papers which we judged to provide a comprehensive description of stakeholder involvement in systematic reviews, and used these examples to summarise different ways in which stakeholders have been involved in systematic reviews. These examples arguably currently provide the best available information to inform and guide decisions around the planning of stakeholder involvement within future systematic reviews. This evidence has been used by Cochrane Training to develop online learning resources relating to how to involve people in systematic reviews [60], and has been used to develop a framework for describing stakeholder involvement in systematic reviews (Pollock A, Campbell P, Struthers C, Synnot A, Nunn J, Hill S, Goodare H, Morris J, Watts C, Morley R: Development and application of a framework to describe how stakeholders have been involved in systematic reviews, submitted).

\section{Additional files}

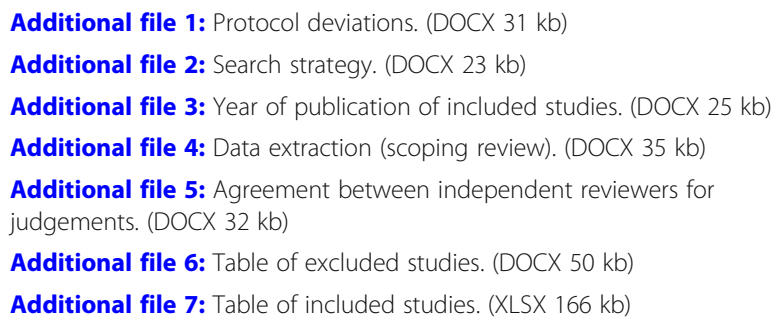

\section{Abbreviations}

ACTIVE: Authors and Consumers Together Impacting on eVidencE; AMED: Allied and Complementary Medicine Database; CDSR: Cochrane Database of Systematic Reviews; CENTRAL: Cochrane Central Register of
Controlled Trials; CINAHL: Cumulative Index to Nursing and Allied Health Literature; DARE: Database of Abstracts of Reviews of Effectiveness; DoPHER: Database of Promoting Health Effectiveness Reviews; EBSCO: An online platform for accessing research databases; Embase: Excerpta Medica Database; EPPI-centre: Evidence for Policy and Practice Information and Coordinating Centre; GRIPP: Guidance for Reporting Involvement of Patients and the Public; HTA: Health Technology Assessment; ICD-10: International Statistical Classification of Diseases and Related Health Problems 10th Revision; MEDLINE: On-line Medical Library database; OVID: An online platform for accessing research databases; PDQ-Evidence: ('Pretty darn quick') database of systematic reviews of health systems evidence

\section{Acknowledgements}

Not applicable

\section{Funding}

The review has been funded by the Learning and Support Department and Consumer Network Co-ordinator, within Cochrane's Central Executive Team. Findings from the review will be used to develop a learning resource to encourage and enable Cochrane Review Groups in involving consumers in Cochrane systematic reviews. Two authors are members of the funding body (RM and CW) and have been involved in conceptualising the design of the study and its outputs.

\section{Availability of data and materials \\ Not applicable}

\section{Authors' contributions}

AP led this review and paper. PC, AS, JN, SH, JM, HG, CW and RM contributed to the conception of the review objectives. AP and PC developed the research methods and design, with comments and feedback from CS, AS, JN, SH, JM, CW and RM. AP and PC ran the searches and applied the selection criteria. CS acted as the third reviewer. AP extracted and synthesised the data and wrote the first draft of the manuscript; PC, AS, $J N, S H, J M, H G, C W$ and RM commented on this draft. All authors read and approved the final manuscript.

\section{Authors' information}

All authors are involved with Cochrane (an international not-for-profit which publishes systematic reviews).

Alex Pollock is a senior research fellow at the Scottish Government funded 'Nursing Midwifery and Allied Health Professions Research Unit' (NMAHP RU) and has been involved in systematic reviews of complex interventions for over 15 years. She is an associate editor of the Cochrane Stroke Group and an author on 12 Cochrane reviews. She has implemented innovative ways of involving stakeholders within Cochrane reviews.

Pauline Campbell is a research fellow at NMAHP RU, with particular responsibility for completing systematic reviews relating to nursing and healthcare interventions, including rapid reviews commissioned by the Scottish Government's Chief Nursing Officer. She is an author on 7 Cochrane reviews and has involved stakeholders in reviews using a range of methods. Caroline Struthers is the education and training manager for the EQUATOR Network, responsible for developing educational resources, courses and training materials for a wide range of users, including researchers, editors, peer reviewers and the general public. Previous roles have included Information Specialist, Managing Editor and Training Coordinator for Cochrane, and she was also manager of an NHS-funded public engagement project for the Cochrane Dementia and Cognitive Impairment Group. At the time of this work, she was a member of the Cochrane Consumer Network Executive.

Anneliese Synnot is a research fellow and editor with Cochrane Consumers and Communication. Her research interests include innovations in evidence synthesis, both in terms of novel methods to involve consumers and others in the review production and dissemination and innovative review types, such as Living Systematic Reviews.

Jack Nunn is a researcher in the Public Health Department in the Centre for Health Communication and Participation at La Trobe University. He has recently worked on projects with Cochrane Australia, the World Health Organisation and the Australian Department of Health. He has previously worked for the UK National Institute of Health Research and Macmillan Cancer Support (UK) where he led the development and implementation of 
an internationally recognised model for building partnerships between the public and researchers.

Sophie Hill is the Head of the Centre for Health Communication and Participation (www.latrobe.edu.au/chcp), at La Trobe University, a centre she has established from the foundation of the Cochrane Consumers and Communication Review Group (http://cccrg.cochrane.org/). The Centre has an applied focus, with three roles: coordinating the production and publication of evidence on interventions to communicate with people about health; innovative research on communication issues that have been neglected, such as multimorbidity; and a knowledge translation function, for getting evidence into practice and policy.

Heather Goodare is a Cochrane consumer reviewer for breast cancer and stroke; she was the first patient representative on the BMJ Editorial Board (1995-1999) and is a Life Fellow of the Royal Society of Medicine. Originally an academic book editor, Heather trained as a counsellor after her own experience of breast cancer and of a flawed research study (Chilvers et al. [64]) in which she was a patient (see Goodare [65]).

Chris Watts is the Learning and Support Officer for Cochrane Training. He works on a range of Cochrane learning projects including design and development of learning materials and pathways to support learners in a variety of Cochrane roles, particularly through online resources and initiatives for distance learners. Chris is a researcher by background and previously worked at the Royal College of Nursing in the UK, where he led a team of Research Analysts delivering evidence synthesis and evaluation projects supporting professional development and policy.

Richard Morley is the Consumer Coordinator for Cochrane, supporting consumer involvement in the production and dissemination of Cochrane evidence. He has extensive experience of public engagement and partnership working in the voluntary, public and education sectors. Jacqui Morris is a Reader in Rehabilitation Research with a particular interest in how systematic review evidence can be implemented in allied health professionals practice. She is a co-author on several Cochrane reviews.

\section{Ethics approval and consent to participate}

Not applicable

\section{Consent for publication}

Not applicable

\section{Competing interests}

The authors declare that they have no competing interests.

\section{Publisher's Note}

Springer Nature remains neutral with regard to jurisdictional claims in published maps and institutional affiliations.

\section{Author details}

${ }^{1}$ Nursing Midwifery and Allied Health Professions (NMAHP) Research Unit, Glasgow Caledonian University, Cowcaddens Road, Glasgow G4 OBA, UK. ${ }^{2}$ EQUATOR Network, Centre for Statistics in Medicine, NDORMS, University of Oxford, Botnar Research Centre, Windmill Road, Oxford OX3 7LD, UK. ${ }^{3}$ Cochrane Consumers and Communication, Centre for Health Communication and Participation, School of Psychology and Public Health, La Trobe University, Kingsbury Drive, Bundoora, Victoria 3086, Australia. ${ }^{4}$ Cochrane Australia, School of Public Health and Preventive Medicine, Monash University, L4, 551 St Kilda Road, Melbourne, Victoria 3004, Australia. ${ }^{5}$ Centre for Health Communication and Participation, School of Psychology and Public Health, La Trobe University, Kingsbury Drive, Bundoora, Victoria 3086, Australia. ${ }^{6}$ Edinburgh, UK. ${ }^{7}$ School of Nursing and Health Sciences, University of Dundee, 11 Airlie Place, Dundee DD1 4HJ, UK. ${ }^{8}$ Cochrane Learning and Support Department, Cochrane Central Executive, St Albans House, 57-59 Haymarket, London SW1Y 4QX, UK. ${ }^{9}$ Cochrane Consumer Network, St Albans House, 57-59 Haymarket, London SW1Y 4QX, UK.

\section{Received: 6 March 2018 Accepted: 22 October 2018}

\section{Published online: 24 November 2018}

\section{References}

1. Camden C, Shikako-Thomas K, Nguyen T, Graham E, Thomas A, Sprung J, Morris C, Russell DJ. Engaging stakeholders in rehabilitation research: a scoping review of strategies used in partnerships and evaluation of impacts. Disabil Rehabil. 2015;37:1390-400.

2. INVOLVE. Exploring the impact of public involvement on the quality of research: examples. Eastleigh: INVOLVE; 2013.

3. Kreis J, Puhan MA, Schunemann HJ, Dickersin K. Consumer involvement in systematic reviews of comparative effectiveness research. Health Expect. 2013; 16:323-37.

4. Concannon TW, Meissner P, Grunbaum JA, McElwee N, Guise J-M, Santa J, Conway PH, Daudelin D, Morrato EH, Leslie LK. A new taxonomy for stakeholder engagement in patient-centered outcomes research. J Gen Intern Med. 2012;27:985-91.

5. Heaton J, Day J, Britten N. Collaborative research and the co-production of knowledge for practice: an illustrative case study. Implement Sci. 2016;11:20.

6. Boote J, Wong R, Booth A. Talking the talk or walking the walk?' A bibliometric review of the literature on public involvement in health research published between 1995 and 2009. Health Expect. 2015;18:44-57.

7. CIHR. Canadian Institutes of Health Research (CIHR): strategy for patientoriented research (SPOR) - patient engagement. Ottawa: CIHR; 2014

8. Hickey G, Richards T, Sheehy J. Co-production from proposal to paper. Nature. 2018;562:29-31.

9. NHMRC. National Health and Medical Research Council (NHMRC): a model framework for consumer and community participation in health and medical research. Canberra: NHMRC; 2005.

10. Nasser M, Clarke M, Chalmers I, Brurberg KG, Nykvist H, Lund H, Glasziou P. What are funders doing to minimise waste in research? Lancet. 2017;389:1006-7.

11. Wallace J, Nwosu B, Clarke M. Barriers to the uptake of evidence from systematic reviews and meta-analyses: a systematic review of decision makers' perceptions. BMJ Open. 2012;2:e001220.

12. Cochrane Consumer Network. http://consumers.cochrane.org/. Accessed 6 Nov 2018.

13. INVOLVE. Briefing notes for researchers: involving the public in NHS, public health and social care research. Eastleigh: INVOLVE; 2012

14. Horey D. Consumer involvement in the Cochrane Collaboration: background paper (strategic session). Auckland: Cochrane Consumer Network; 2010.

15. Cochrane Consumer Network. Cochrane consumer network structure and function review, 2015. https://consumers.cochrane.org/ccnet-structure-andfunction-review. Accessed 6 Nov 2018.

16. Boote J, Baird W, Sutton A. Public involvement in the systematic review process in health and social care: a narrative review of case examples. Health Policy. 2011;102:105-16.

17. Morley RF, Norman G, Golder S, Griffith P. A systematic scoping review of the evidence for consumer involvement in organisations undertaking systematic reviews: focus on Cochrane. Res Involv Engagem. 2016;2:36.

18. Domecq JP, Prutsky G, Elraiyah T, Wang Z, Nabhan M, Shippee N, Brito JP, Boehmer K, Hasan R, Firwana B, et al. Patient engagement in research: a systematic review. BMC Health Serv Res. 2014;14:89.

19. ACTIVE: Authors and Consumers Together Impacting eVidencE. http:// training.cochrane.org/ACTIVE. Accessed 6 Nov 2018.

20. Pollock A, Campbell P, Struthers C, Synnot A, Nunn J, Hill S, Goodare H, Watts C, Morley R. Stakeholder involvement in systematic reviews: a protocol for a systematic review of methods, outcomes and effects. Res Involv Engagem. 2017;3:9.

21. Arksey H, O'Malley L. Scoping studies: towards a methodological framework. Int J Soc Res Methodol. 2005;8:19-32.

22. Levac D, Colquhoun H, O'Brien KK. Scoping studies: advancing the methodology. Implement Sci. 2010;5:69.

23. Colquhoun HL, Levac D, O'Brien KK, Straus S, Tricco AC, Perrier L. Scoping reviews: time for clarity in definition, methods, and reporting. J Clin Epidemiol. 2014;67:1291-4

24. Jepson R, Harris F, MacGillivray S, Kearney N, Roaw-Dewar N. A review of the effectiveness of interventions, approaches and models at individual, community and population level that are aimed at changing health outcomes through changing knowledge attitudes and behaviour; 2007

25. Harris J, Croot L, Thompson J, Springett J. How stakeholder participation can contribute to systematic reviews of complex interventions. J Epidemiol Community Health. 2016;70:207-14.

26. Cochrane Consumer Network. http://consumers.cochrane.org/healthcareusers-cochrane. Accessed 6 Nov 2018

27. Evidence-informed policy and practice (EPPI) centre: what is a systematic review? http://eppi.ioe.ac.uk/cms/Default.aspx?tabid=67. Accessed 6 Nov 2018. 
28. Pollock A, Campbell P, Deery R, Fleming M, Rankin J, Sloan G, Cheyne H. A systematic review of evidence relating to clinical supervision for nurses, midwives and allied health professionals. J Adv Nurs. 2017;10:1825-37.

29. Bayliss K, Starling B, Raza K, Johansson EC, Zabalan C, Moore S, Skingle D, Jasinski T, Thomas S, Stack R. Patient involvement in a qualitative metasynthesis: lessons learnt. Res Involv Engagem. 2016;2. https://doi.org/10. 1186/s40900-016-0032-0.

30. Boelens PG, Taylor C, Henning G, Marang-van de Mheen PJ, Espin E, Wiggers T, Gore-Booth J, Moss B, Valentini V, van de Velde CJ. Involving patients in a multidisciplinary European consensus process and in the development of a 'patient summary of the consensus document for colon and rectal cancer care'. Patient. 2014;7:261-70.

31. Braye S, Preston-Shoot M. Emerging from out of the shadows? Service user and carer involvement in systematic reviews. Evid Policy. 2005;1:173-94.

32. Bunn F, Sworn K, Brayne C, lliffe S, Robinson L, Goodman C. Contextualizing the findings of a systematic review on patient and carer experiences of dementia diagnosis and treatment: a qualitative study. Health Expect. 2015;18:740-53.

33. Coon JT, Gwernan-Jones R, Moore D, Richardson M, Shotton C, Pritchard W, Morris C, Stein K, Ford T. End-user involvement in a systematic review of quantitative and qualitative research of non-pharmacological interventions for attention deficit hyperactivity disorder delivered in school settings: reflections on the impacts and challenges. Health Expect. 2016;19:1084-97.

34. Hyde C, Dunn KM, Higginbottom A, Chew-Graham CA. Process and impact of patient involvement in a systematic review of shared decision making in primary care consultations. Health Expect. 2017;20:298-308.

35. Jamal F, Langford R, Daniels P, Thomas J, Harden A, Bonell C. Consulting with young people to inform systematic reviews: an example from a review on the effects of schools on health. Health Expect. 2015;18:3225-35.

36. Martin S, Fleming J, Cullum S, Dening T, Rait G, Fox C, Katona C, Brayne C, Lafortune L. Exploring attitudes and preferences for dementia screening in Britain: contributions from carers and the general public. BMC Geriatr. 2015;15:110.

37. Oliver K, Rees R, Brady LM, Kavanagh J, Oliver S, Thomas J. Broadening public participation in systematic reviews: a case example involving young people in two configurative reviews. Res Synth Methods. 2015;6:206-17.

38. Pollock A, Campbell P, Baer G, Choo PL, Morris J, Forster A. User involvement in a Cochrane systematic review: using structured methods to enhance the clinical relevance, usefulness and usability of a systematic review update. Syst Rev. 2015;4:55.

39. Serrano-Aguilar P, Trujillo-Martin MM, Ramos-Goni JM, Mahtani-Chugani V, Perestelo-Perez L, Posada-de la Paz M. Patient involvement in health research: a contribution to a systematic review on the effectiveness of treatments for degenerative ataxias. Soc Sci Med. 2009;69:920-5.

40. Stewart R, Oliver S. What is known about communication with parents about newborn bloodspot screening? In: Carr S, Coren E, editors. Collection of examples of service user and carer participation in systematic reviews. London: Social Care Institute for Excellence; 2003.

41. Vale C, Nightingale A, Spera N, Whelan A, Hanley B, Tierney JF. Late complications from chemoradiotherapy for cervical cancer: reflections from cervical cancer survivors 10 years after the national cancer institute alert. Clin Oncol (R Coll Radiol). 2010;22:588-9.

42. Concannon TW, Fuster M, Saunders T, Patel K, Wong JB, Leslie LK, Lau $J$. A systematic review of stakeholder engagement in comparative effectiveness and patient-centered outcomes research. J Gen Intern Med. 2014;29:1692-701.

43. Edwards D, Evans N, Gillen E, Longo M, Pryjmachuk S, Trainor G, Hannigan B. What do we know about the risks for young people moving into, through and out of inpatient mental health care? Findings from an evidence synthesis. Child Adolesc Psychiatry Ment Health. 2015;9:55.

44. Hayden JA, Killian L, Zygmunt A, Babineau J, Martin-Misener R, Jensen JL, Carter AJ. Methods of a multi-faceted rapid knowledge synthesis project to inform the implementation of a new health service model: collaborative emergency centres. Syst Rev. 2015;4:7.

45. Higginson IJ, Evans CJ, Grande G, Preston N, Morgan M, McCrone P, Lewis P, Fayers $\mathrm{P}$, Harding R, Hotopf $\mathrm{M}$, et al. Evaluating complex interventions in end of life care: the MORECare statement on good practice generated by a synthesis of transparent expert consultations and systematic reviews. BMC Med. 2013;11:111.

46. Liabo K. Service user involvement in research: collaborating on a systematic review with young people who have experience of being in care. London: University of London, Institute of Education; 2013.

47. Liu J, Davidson E, Bhopal R, White M, Johnson M, Netto G, Deverill M, Sheikh A. Adapting health promotion interventions to meet the needs of ethnic minority groups: mixed-methods evidence synthesis. Health Technol Assess. 2012;16(44). https://doi.org/10.3310/hta16440.

48. McConachie H, Parr JR, Glod M, Hanratty J, Livingstone N, Oono IP, Robalino S, Baird G, Beresford B, Charman T, et al. Systematic review of tools to measure outcomes for young children with autism spectrum disorder. Health Technol Assess. 2015;19:1-506.

49. McCusker J, Yaffe M, Sussman T, Kates N, Mulvale G, Jayabarathan A, Law S, Haggerty J. Developing an evaluation framework for consumer-centred collaborative care of depression using input from stakeholders. Can J Psychiatr. 2013:58:160-8.

50. Pearson M, Chilton R, Wyatt K, Abraham C, Ford T, Woods HB, Anderson R. Implementing health promotion programmes in schools: a realist systematic review of research and experience in the United Kingdom. Implement Sci. 2015;10:149.

51. Rees R, Kavanagh J, Burchett H, Shepherd J, Brunton G, Harden A, Thomas J, Oliver S, Oakley A. HIV health promotion and men who have sex with men (MSM): a systematic review of research relevant to the development and implementation of effective and appropriate interventions. London: EPPI-Centre; 2004.

52. Smith E, Ross F, Donovan S, Manthorpe J, Brearley S, Sitzia J, Beresford P. Service user involvement in nursing, midwifery and health visiting research: a review of evidence and practice. Int J Nurs Stud. 2008:45:298-315.

53. Bond KS, Chalmers KJ, Jorm AF, Kitchener BA, Reavley NJ. Assisting Australians with mental health problems and financial difficulties: a Delphi study to develop guidelines for financial counsellors, financial institution staff, mental health professionals and carers. BMC Health Serv Res. 2015;15:218.

54. Oosterkamp BC, van der Sanden WJ, Frencken JE, Kuijpers-Jagtman AM. Caries preventive measures in orthodontic practice: the development of a clinical practice guideline. Orthod Craniofacial Res. 2016;19:36-45.

55. Saan MC, Boeije HR, Sattoe JN, Bal MI, Missler M, van Wesel F. Recording and accounting for stakeholder involvement in systematic reviews. Health Inf Libr J. 2015;32:95-106.

56. McGinn CA, Gagnon M-P, Shaw N, Sicotte C, Mathieu L, Leduc Y, Grenier S, Duplantie J, Abdeljelil AB, Légaré F. Users' perspectives of key factors to implementing electronic health records in Canada: a Delphi study. BMC Med Inform Decis Mak. 2012;12:105.

57. Hesselink G, Kuis E, Pijnenburg M, Wollersheim H. Measuring a caring culture in hospitals: a systematic review of instruments. BMJ Open. 2013;3:e003416.

58. Morgan H, Hoddinott P, Thomson G, Crossland N, Farrar S, Yi D, Hislop J, Moran VH, MacLennan G, Dombrowski SU, et al. Benefits of incentives for Breastfeeding and Smoking cessation in pregnancy (BIBS): a mixed-methods study to inform trial design. Health Technol Assess. 2015;19:1-522 vii-viii.

59. Staniszewska S, Brett J, Mockford C, Barber R. The GRIPP checklist: strengthening the quality of patient and public involvement reporting in research. Int J Technol Assess Health Care. 2011;27:391-9.

60. Involving people: a learning resource for systematic review authors. http:// training.cochrane.org/involving-people. Accessed 6 Nov 2018.

61. Dudley L, Gamble C, Allam A, Bell P, Buck D, Goodare H, Hanley B, Preston J, Walker A, Williamson P, Young B. A little more conversation please? Qualitative study of researchers' and patients' interview accounts of training for patient and public involvement in clinical trials. Trials. 2015;16:190.

62. Staniszewska S, Brett J, Simera I, Seers K, Mockford C, Goodlad S, Altman DG, Moher D, Barber R, Denegri S, et al. GRIPP2 reporting checklists: tools to improve reporting of patient and public involvement in research. BMJ. 2017;358:j3453.

63. Hoddinott P, Pollock A, O'Cathain A, Boyer I, Taylor J, MacDonald C, Oliver S, Donovan JL. How to incorporate patient and public perspectives into the design and conduct of research [version 1; referees: 2 approved, 2 approved with reservations]. F1000Research 2018;7:752. https://doi.org/10.12688/ f1000research.15162.1.

64. Chilvers CED, Bagenal FS, Easton DF, Harris E, McElwain TJ. Survival of patients with breast cancer attending Bristol Cancer Help Centre. The Lancet, 1990;336:606-10

65. Goodare $\mathrm{H}$ (Editor). Fighting Spirit: the stories of women in the Bristol breast cancer survey. London; Scarlet Press, 1996. 